\title{
Multidisciplinary involvement and potential of thermophiles
}

\author{
Bhagwan Rekadwad**1, Juan M. Gonzalez ${ }^{2}$ \\ ${ }^{1}$ National Centre for Microbial Resource, National Centre for Cell Science, \\ NCCS Complex, Savitribai Phule Pune University Campus, Ganeshkhind Road, \\ Pune-411007, India. E mail: rekadwad@gmail.com \\ ${ }^{2}$ Microbial diversity and microbiology of extreme environments research group, \\ Agencia Estatal Consejo Superior de Investigaciones Científicas, IRNAS-CSIC, Avda. \\ Reina Mercedes, 10, 41012 Sevilla, Spain. E mail: jmgrau@ irnase.csic.es
}

\begin{abstract}
The full biotechnological exploitation of thermostable enzymes in industrial processes is necessary for their commercial interest and industrious value. The heat tolerant and heat resistant enzymes are a key for efficient and cost-effective translation of substrates into useful products for commercial applications. The thermophilic, hyperthermophilic and microorganisms adapted to extreme temperatures (i.e, low-temperature lovers or psychrophiles) are a rich source of thermostable enzymes with broad ranging thermal properties, which have structural and functional stability to underpin a variety of technologies. These enzymes are under scrutiny for their great biotechnological potential. Temperature is one of the most critical parameters that shape microorganisms and their biomolecules for stability under harsh environmental conditions. This review describes in detail the sources of thermophiles and thermostable enzymes from prokaryotes and eukaryotes (microbial cell factories). Furthermore, the review critically examines perspectives to improve modern biocatalysts, its production and performance aiming to increase their value for biotechnology through higher standards, specificity, resistance, lowing costs, etc. These thermostable and thermally-adapted extremophilic enzymes have been used in a wide range of industries that span all six enzyme classes. Thus, in particular, target of this review paper is to show the possibility of both high value-low volume (e.g. finechemical synthesis) and low value-high volume byproducts (e.g. fuels) by minimizing changes to current industrial processes.
\end{abstract}

Keywords Tailor-made enzymes; Thermoadaptation for Sustainability; Genome mining for thermozymes; "Hot" acetogenesis; Green chemistry

\section{Introduction}

Some microorganisms are metabolically active in physically and geochemically extreme environments. Challenging brutal conditions trait them to expand their capabilities to grow at the physico-chemical boundaries of life such as high salt $(>1.0 \mathrm{~mol} / \mathrm{L})$, low or high $\mathrm{pH}(>8.0$ or $<5.0$ ), very low at very high temperature (less than $1-15{ }^{\circ} \mathrm{C}$ or greater than $45{ }^{\circ} \mathrm{C}$ ), atmospheric pressure (average $380 \mathrm{mmHg}$ ), >500-1200 mmHg (maximum and beyond this), very frequent high radiations, degradation of xenobiotic or recalcitrant toxic chemical, heavy and toxic metals and in the presence of inhibitors. Microorganisms growing in these hostile conditions are named 'extremophiles'. Bacteria, Archaea and Eukarya inhabiting extreme environment have diverse cell structure, unique metabolism and ultimate survival strategies which allows them to withstand at changing unpleasant conditions viz. acidic, alkaline, haline, high temperatures, low temperatures, etc. Extremophiles capable of growth at natural and artificial high temperature environments are called 'thermophiles'. Several extreme high temperature environments have been reported. High temperature niches on our Blue planet exists as natural habitats viz. hot springs, volcanoes, desert, solar salterns, solfataric fields, solar heated soils, fumaroles and hydrothermal vents and artificial habitats viz. compost piles, slag heap, haystacks, industrial processes, domestic laundries, solar panels, hot diaphragm of air conditioner, water heaters and refrigerators (Fig.1). 


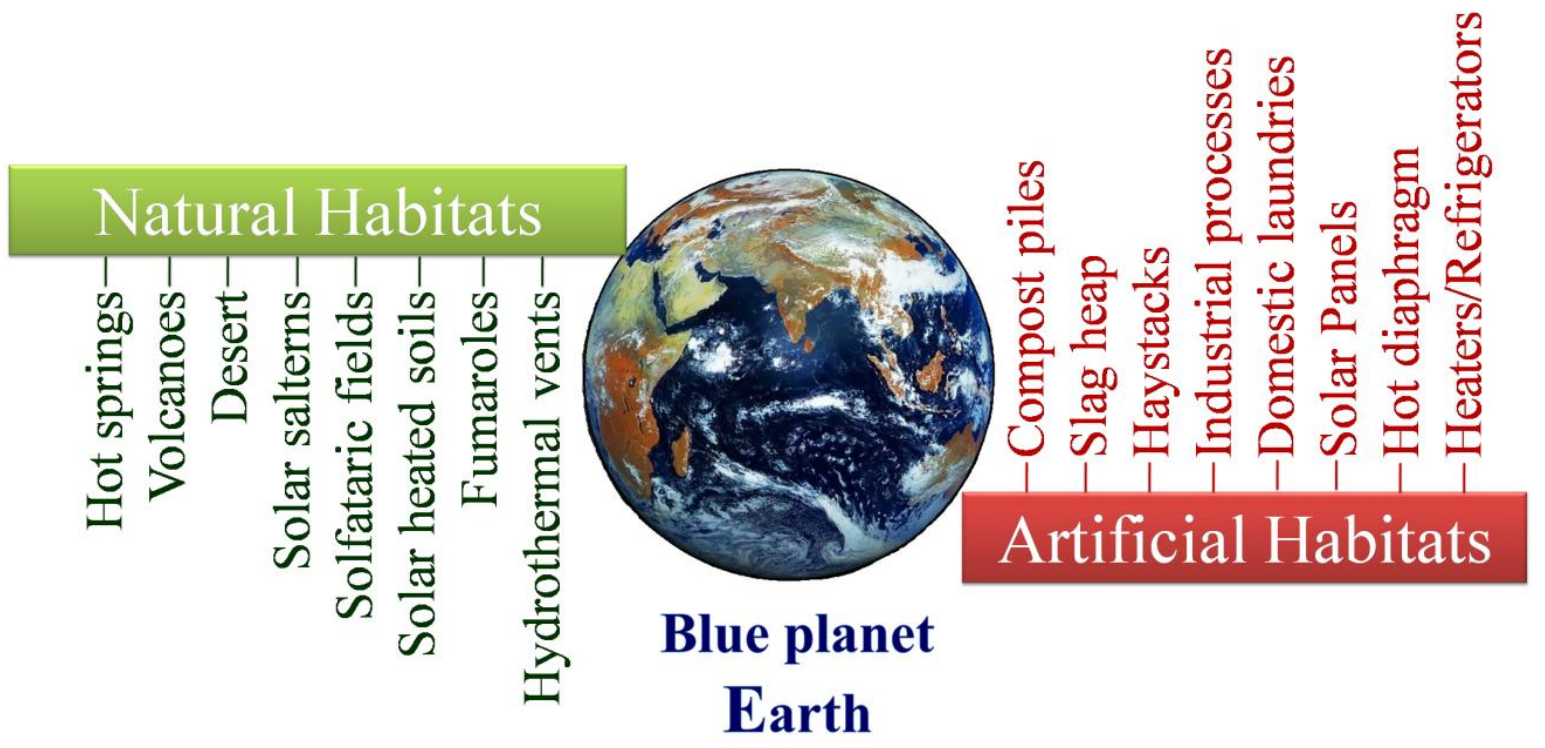

Fig.1 Natural and artificial habitats of thermophiles

Thermophiles have been isolated and identified from different high temperature environments. But, relatively little number of thermophiles are commercially exploited. Recently, novel thermophilic genera and species were isolated from different environments. Thermophiles are waiting for attention of scientist and exploit their characteristics for the benefits to mankind (Table 1). These heat loving microorganisms have inherent the ability to grow and carry out all the metabolic processes optimally at extremes. They have genetically transferable eco-physiological and functional metabolic systems, which assist them to thrive under these conditions. The thermoenzymes, important proteins and polymers produced by thermophiles are structurally stable to function in wide ranges of temperatures, and, generally, also extreme $\mathrm{pHs}$ and withstand the presence of high or low salt concentrations, high pressure, radiations and inhibitors (Rekadwad and Gonzalez, 2017).

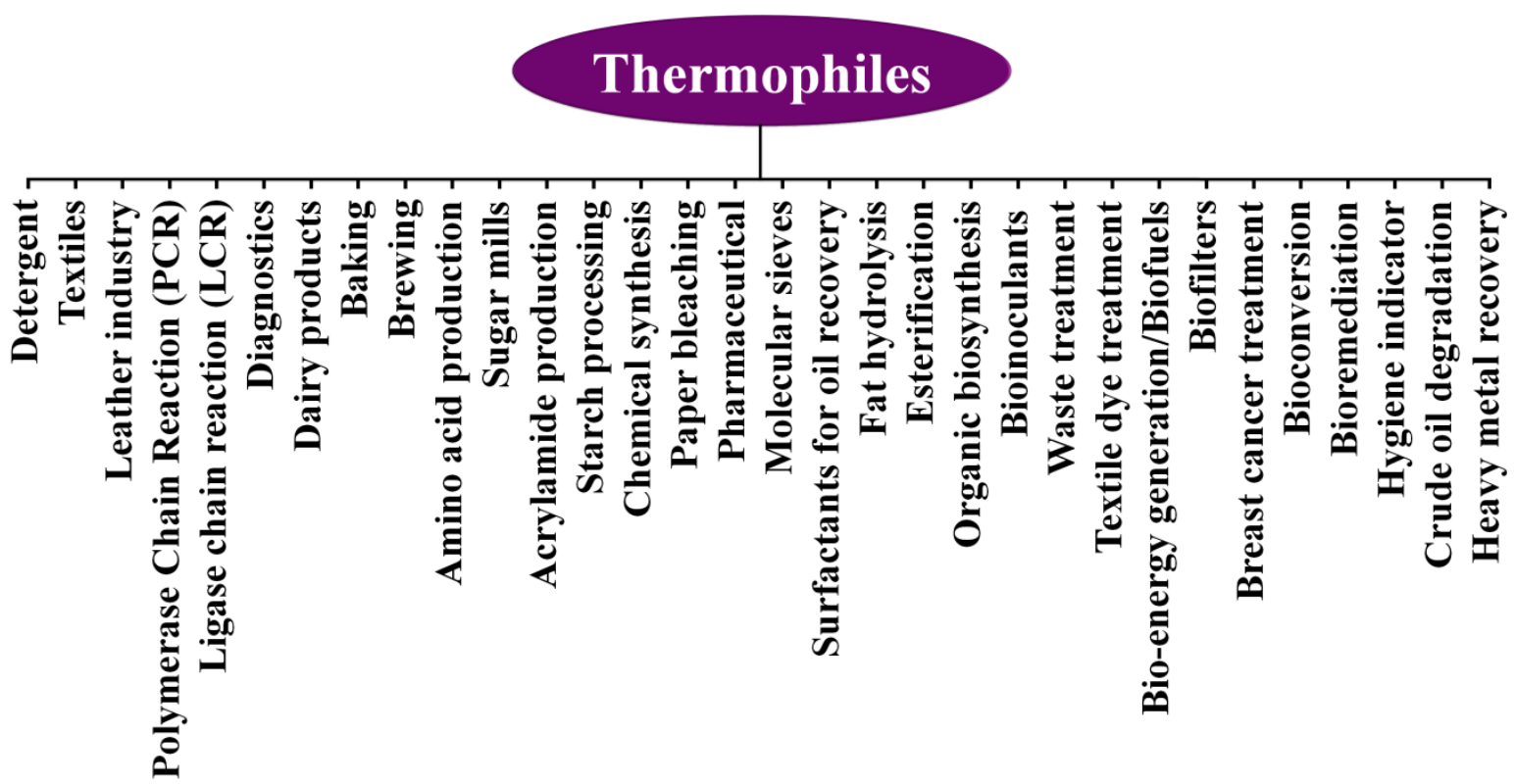

Fig. 2 A number of industrial applications of thermophiles and their products in White Biotechnology 
Table 1. Novel thermophiles isolated and identified from high temperature environments

\begin{tabular}{|c|c|c|c|c|c|}
\hline Genus/Species & Strain (s) & Key feature (s) & Habitat (s) & Country & Reference \\
\hline $\begin{array}{l}\text { Aeribacillus composti } \\
\text { sp. nov. }\end{array}$ & N. $8^{\mathrm{T}}$ & $\begin{array}{l}\text { Found in curing } \\
\text { step of an olive } \\
\text { mill pomace } \\
\text { compost sample } \\
\text { and form cream } \\
\text { colored colonies }\end{array}$ & $\begin{array}{l}\text { Olive mill } \\
\text { pomace } \\
\text { compost }\end{array}$ & Italy & $\begin{array}{l}\text { Finore et al. } \\
2017\end{array}$ \\
\hline $\begin{array}{l}\text { Bacillus hisashii sp. } \\
\text { nov. }\end{array}$ & $\mathrm{N}-11^{\mathrm{T}}$ & $\begin{array}{l}\text { Isolated from } \\
\text { Mice }\end{array}$ & $\begin{array}{l}\text { Caeca of } \\
\text { gnotobiotic } \\
\text { mice fed with } \\
\text { fermented } \\
\text { compost }\end{array}$ & Japan & $\begin{array}{l}\text { Nishida et } \\
\text { al. } 2015\end{array}$ \\
\hline $\begin{array}{l}\text { Bifidobacterium } \\
\text { apri sp. nov. }\end{array}$ & $R P 115^{T}$ & $\begin{array}{l}\text { Utilize fructose- } \\
\text { 6-phosphate } \\
\text { phosphoketolase } \\
\text { and strictly } \\
\text { anaerobic }\end{array}$ & $\begin{array}{l}\text { Digestive tract } \\
\text { of wild pigs }\end{array}$ & $\begin{array}{l}\text { Czech } \\
\text { Republic }\end{array}$ & $\begin{array}{l}\text { Pechar et al. } \\
\text { 2017a }\end{array}$ \\
\hline $\begin{array}{l}\text { Brassicibacter } \\
\text { thermophilus sp. nov. }\end{array}$ & Cel2f $f^{T}$ & $\begin{array}{l}\text { Obligately } \\
\text { anaerobic } \\
\text { bacterium }\end{array}$ & $\begin{array}{l}\text { Coastal marine } \\
\text { sediment }\end{array}$ & China & $\begin{array}{l}\text { Wang et al. } \\
2015\end{array}$ \\
\hline $\begin{array}{l}\text { Caldovatus } \\
\text { sediminis gen. nov., sp. } \\
\text { nov. }\end{array}$ & YIM $\underset{T}{72346}$ & $\begin{array}{l}\text { Non-motile } \\
\text { bacterium with } \\
\text { predominant } \\
\text { ubiquinone was } \\
\text { Q-10 }\end{array}$ & $\begin{array}{l}\text { Hot spring, } \\
\text { Tengchong } \\
\text { county, Yunnan } \\
\text { province }\end{array}$ & China & $\begin{array}{l}\text { Habib et al. } \\
2017 \mathrm{a}\end{array}$ \\
\hline $\begin{array}{l}\text { Caloranaerobacter } \\
\text { ferrireducens sp. nov. }\end{array}$ & DY22619 ${ }^{\mathrm{T}}$ & $\begin{array}{l}\text { Presence of } \\
\text { multiple } \\
\text { peritrichous } \\
\text { flagella }\end{array}$ & $\begin{array}{l}\text { Hydrothermal } \\
\text { field, East } \\
\text { Pacific Ocean }\end{array}$ & China & $\begin{array}{l}\text { Zeng et al. } \\
\quad 2015\end{array}$ \\
\hline $\begin{array}{l}\text { Cecembia rubra sp. } \\
\text { nov. }\end{array}$ & YIM 78110 & $\begin{array}{l}\text { Phosphatidyletha } \\
\text { nolamine is } \\
\text { major polar lipid }\end{array}$ & $\begin{array}{l}\text { Hehua } \\
\text { spring }\end{array}$ & China & $\begin{array}{l}\text { Duan et al. } \\
\quad 2015\end{array}$ \\
\hline $\begin{array}{l}\text { Cetia pacifica gen. } \\
\text { nov., sp. nov. }\end{array}$ & TB- $6^{\mathrm{T}}$ & $\begin{array}{l}\text { Chemolithoautot } \\
\text { rophic bacterium }\end{array}$ & $\begin{array}{l}\text { Deep-sea } \\
\text { hydrothermal } \\
\text { vent }\end{array}$ & USA & $\begin{array}{l}\text { Grosche et } \\
\text { al. } 2015\end{array}$ \\
\hline $\begin{array}{l}\text { Chloroflexus } \\
\text { islandicus sp. nov. }\end{array}$ & isl $-2^{\mathrm{T}}$ & $\begin{array}{l}\text { Anoxygenic } \\
\text { phototrophic } \\
\text { non-spore } \\
\text { forming } \\
\text { bacterium, } \\
\text { unbranched } \\
\text { multicellular } \\
\text { filaments with } \\
\text { gliding motility }\end{array}$ & $\begin{array}{l}\text { Strokkur Geyser } \\
\text { basin }\end{array}$ & Iceland & $\begin{array}{l}\text { Gaisin et al. } \\
\quad 2017\end{array}$ \\
\hline $\begin{array}{l}\text { Crenalkalicoccus } \\
\text { roseus gen. nov., sp. } \\
\text { nov. }\end{array}$ & $\begin{array}{c}\text { YIM } \\
78023^{\mathrm{T}} \text { and } \\
\text { YIM } \\
78058^{\mathrm{T}}\end{array}$ & $\begin{array}{l}\text { Grew at } \mathrm{pH} 6.0- \\
10.0\end{array}$ & $\begin{array}{l}\text { Alkaline hot } \\
\text { springs, } \\
\text { Tengchong } \\
\text { county, Yunnan } \\
\text { province }\end{array}$ & China & $\begin{array}{l}\text { Ming et al. } \\
2016\end{array}$ \\
\hline $\begin{array}{l}\text { Deferrisoma } \\
\text { palaeochoriense sp. } \\
\text { nov. }\end{array}$ & MAG-PB1 ${ }^{\mathrm{T}}$ & $\begin{array}{l}\text { Iron(III) } \\
\text { reducing, } \\
\text { anaerobic, } \\
\text { mixotrophic }\end{array}$ & $\begin{array}{l}\text { Hydrothermal } \\
\text { vent system, } \\
\text { Palaeochori Bay } \\
\text { off the coast of }\end{array}$ & Greece & $\begin{array}{l}\text { Pérez- } \\
\text { Rodríguez et } \\
\text { al. } 2016\end{array}$ \\
\hline
\end{tabular}




\begin{tabular}{|c|c|c|c|c|c|}
\hline & & bacterium & $\begin{array}{l}\text { the island of } \\
\text { Milos }\end{array}$ & & \\
\hline $\begin{array}{l}\text { Defluviitalea } \\
\text { raffinosedens sp. nov. }\end{array}$ & $\mathrm{A} 6^{\mathrm{T}}$ & $\begin{array}{l}\text { Yeast extract } \\
\text { was required for } \\
\text { growth. }\end{array}$ & $\begin{array}{l}\text { Anaerobic batch } \\
\text { digester treating } \\
\text { animal manure } \\
\text { and rice straw }\end{array}$ & China & $\begin{array}{l}\text { Ma et al. } \\
2017\end{array}$ \\
\hline $\begin{array}{l}\text { Desulfotomaculum } \\
\text { ferrireducens sp. nov. }\end{array}$ & GSSO9 ${ }^{\mathrm{T}}$ & $\mathrm{Fe}(\mathrm{III})$-reduction & $\begin{array}{l}\text { Composting } \\
\text { demonstration } \\
\text { plant, } \\
\text { Dongguan City, } \\
\text { Guangdong } \\
\text { Province }\end{array}$ & China & $\begin{array}{l}\text { Yang et al. } \\
2016\end{array}$ \\
\hline $\begin{array}{l}\text { Desulfurobacterium } \\
\text { indicum sp. nov. }\end{array}$ & $\mathrm{K} 6013^{\mathrm{T}}$ & $\begin{array}{l}\text { Obligate } \\
\text { chemolithoautotr } \\
\text { oph utilize } \\
\text { thiosulfate, } \\
\text { sulfur and nitrate } \\
\text { as terminal } \\
\text { electron } \\
\text { acceptors in the } \\
\text { presence of } \\
\mathrm{H}_{2} \text { but not } \\
\text { sulfate, sulfite } \\
\text { nor nitrite }\end{array}$ & $\begin{array}{l}\text { Sulfide sample } \\
\text { from high- } \\
\text { temperature } \\
\text { hydrothermal } \\
\text { vent in the } \\
\text { Indian Ocean }\end{array}$ & China & $\begin{array}{l}\text { Cao et al. } \\
2017\end{array}$ \\
\hline $\begin{array}{l}\text { Dissulfurimicrobium } \\
\text { hydrothermale gen. } \\
\text { nov., sp. nov. }\end{array}$ & $\operatorname{Sh} 68^{\mathrm{T}}$ & $\begin{array}{l}\text { Sulphur utilizing } \\
\text { bacterium }\end{array}$ & $\begin{array}{l}\text { Hydrothermal } \\
\text { pond at Uzon } \\
\text { Caldera, } \\
\text { Kamchatka }\end{array}$ & Russia & $\begin{array}{l}\text { Slobodkin et } \\
\text { al. } 2016\end{array}$ \\
\hline $\begin{array}{l}\text { Dissulfurirhabdus } \\
\text { thermomarina gen. } \\
\text { nov., sp. nov. }\end{array}$ & SH388 ${ }^{\mathrm{T}}$ & Sulfite-reduction & $\begin{array}{l}\text { Shallow-sea } \\
\text { hydrothermal } \\
\text { vent, Kuril } \\
\text { Islands }\end{array}$ & Russia & $\begin{array}{l}\text { Slobodkina } \\
\text { et al. 2016a }\end{array}$ \\
\hline $\begin{array}{l}\text { Fervidobacterium } \\
\text { thailandense sp. nov. }\end{array}$ & $\mathrm{FC} 2004^{\mathrm{T}}$ & $\begin{array}{l}\text { Strictly } \\
\text { anaerobic, } \\
\text { extremely } \\
\text { thermophilic } \\
\text { heterotroph }\end{array}$ & Hot spring & Thailand & $\begin{array}{l}\text { Kanoksilapa } \\
\text { tham et al. } \\
2016\end{array}$ \\
\hline $\begin{array}{l}\text { Galliscardovia } \\
\text { ingluviei gen. nov., sp. } \\
\text { nov. }\end{array}$ & $\mathrm{RP} 1^{\mathrm{T}}$ & $\begin{array}{l}\text { Utilize fructose- } \\
\text { 6-phosphate } \\
\text { phosphoketolase }\end{array}$ & $\begin{array}{lr}13 \text {-month-old } \\
\text { Hisex } & \text { Brown } \\
\text { hybrid } & \text { laying } \\
\text { hen } & \\
\end{array}$ & $\begin{array}{l}\text { Czech } \\
\text { Republic }\end{array}$ & $\begin{array}{l}\text { Pechar et al. } \\
\text { 2017b }\end{array}$ \\
\hline $\begin{array}{l}\text { Geobacillus } \\
\text { icigianus sp. nov. }\end{array}$ & $\mathrm{G} 1 \mathrm{w} 1^{\mathrm{T}}$ & $\begin{array}{l}\text { Motile, } \\
\text { thermophilic } \\
\text { spore-forming } \\
\text { strain }\end{array}$ & $\begin{array}{l}\text { Hot spring of } \\
\text { the Valley of } \\
\text { Geysers, } \\
\text { Kamchatka }\end{array}$ & Russia & $\begin{array}{l}\text { Bryanskaya } \\
\text { et al. } 2015\end{array}$ \\
\hline $\begin{array}{l}\text { Geobacillus } \\
\text { yumthangensis sp. nov. }\end{array}$ & $\mathrm{AYN} 2^{\mathrm{T}}$ & $\begin{array}{l}\text { Alkalophilic } \\
\text { bacterium }\end{array}$ & \begin{tabular}{l}
\multicolumn{2}{l}{ Yumthang hot } \\
spring, North \\
Sikkim
\end{tabular} & India & $\begin{array}{l}\text { Najar et al. } \\
\quad 2018\end{array}$ \\
\hline $\begin{array}{l}\text { Herbinix } \\
\text { hemicellulosilytica gen. } \\
\text { nov. }\end{array}$ & $\mathrm{T} 3 / 55^{\mathrm{T}}$ & $\begin{array}{l}\text { Cellulose- } \\
\text { degrading } \\
\text { bacterium }\end{array}$ & Biogas reactor & Germany & $\begin{array}{l}\text { Koeck et al. } \\
\quad 2015\end{array}$ \\
\hline $\begin{array}{l}\text { Herbinix luporum sp. } \\
\text { nov. }\end{array}$ & $\mathrm{SD}_{1}{ }^{\mathrm{T}}$ & $\begin{array}{l}\text { Degrade } \\
\text { crystalline } \\
\text { cellulose }\end{array}$ & Biogas reactor & Germany & $\begin{array}{l}\text { Koeck et al. } \\
\text { 2016a }\end{array}$ \\
\hline
\end{tabular}




\begin{tabular}{|c|c|c|c|c|c|}
\hline $\begin{array}{l}\text { Herbivorax } \\
\text { saccincola gen. nov., } \\
\text { sp. nov. }\end{array}$ & $\mathrm{GGR} 1^{\mathrm{T}}$ & $\begin{array}{l}\text { Cellulolytic } \\
\text { bacterium }\end{array}$ & $\begin{array}{l}\text { Lab-scale } \\
\text { biogas } \\
\text { fermenter }\end{array}$ & Germany & $\begin{array}{l}\text { Koeck et al. } \\
\quad 2016 b\end{array}$ \\
\hline $\begin{array}{l}\text { Kyrpidia spormannii } \\
\text { sp. Nov. }\end{array}$ & EA- $1^{\mathrm{T}}$ & $\begin{array}{l}\text { Hydrogen- } \\
\text { oxidizing } \\
\text { bacterium }\end{array}$ & $\begin{array}{l}\text { Hydrothermal } \\
\text { systems at São } \\
\text { Miguel Island }\end{array}$ & Portugal & $\begin{array}{l}\text { Reiner et al. } \\
\quad 2018\end{array}$ \\
\hline $\begin{array}{l}\text { Laceyella } \\
\text { thermophila sp. nov. }\end{array}$ & $\begin{array}{c}\text { YIM } \\
79486^{\mathrm{T}}\end{array}$ & $\begin{array}{l}\text { Produce } \\
\text { abundant } \\
\text { endospores on } \\
\text { short } \\
\text { sporophores }\end{array}$ & $\begin{array}{l}\text { Jinze hot spring } \\
\text { in Tengchong } \\
\text { county, Yunnan } \\
\text { province }\end{array}$ & China & $\begin{array}{l}\text { Ming et al. } \\
2017\end{array}$ \\
\hline $\begin{array}{l}\text { Limisphaera } \\
\text { ngatamarikiensis gen. } \\
\text { nov., sp. nov. }\end{array}$ & NGM72. $4^{\mathrm{T}}$ & $\begin{array}{l}\text { Pink-pigmented } \\
\text { Verrucomicrobia }\end{array}$ & $\begin{array}{l}\text { Hot spring in } \\
\text { the Ngatamariki } \\
\text { geothermal field }\end{array}$ & $\begin{array}{l}\text { New } \\
\text { Zealand }\end{array}$ & $\begin{array}{l}\text { Anders et al. } \\
\quad 2015\end{array}$ \\
\hline $\begin{array}{l}\text { Limnochorda pilosa } \\
\text { gen. nov., sp. nov. }\end{array}$ & $\mathrm{HC} 45^{\mathrm{T}}$ & $\begin{array}{l}\text { Facultatively } \\
\text { anaerobic, } \\
\text { pleomorphic } \\
\text { bacterium } \\
\end{array}$ & $\begin{array}{l}\text { Brackish } \\
\text { meromictic lake }\end{array}$ & Japan & $\begin{array}{l}\text { Watanabe et } \\
\text { al. } 2015\end{array}$ \\
\hline $\begin{array}{l}\text { Marinitoga arctica sp. } \\
\text { nov. }\end{array}$ & $2 \operatorname{PyrY} 55-1^{\mathrm{T}}$ & $\begin{array}{l}\text { Possesses a polar } \\
\text { flagellum and a } \\
\text { sheath-like outer } \\
\text { structure ('toga') }\end{array}$ & $\begin{array}{l}\text { Hydrothermal } \\
\text { white-smoker } \\
\text { chimney, Soria } \\
\text { Moria vent } \\
\text { field, Mohns } \\
\text { Ridge, } \\
\text { Norwegian- } \\
\text { Greenland Sea }\end{array}$ & Norwey & $\begin{array}{l}\text { Steinsbu et } \\
\text { al. } 2016\end{array}$ \\
\hline $\begin{array}{l}\text { Meiothermus luteus sp. } \\
\text { nov. }\end{array}$ & $\begin{array}{l}\text { YIM } \\
72257^{\mathrm{T}}\end{array}$ & $\begin{array}{l}\text { Presence of } \\
\text { uncharacterized } \\
\text { phospholipid and } \\
\text { two glycolipids }\end{array}$ & $\begin{array}{l}\text { Hot spring in } \\
\text { Tengchong } \\
\text { county, Yunnan } \\
\text { province }\end{array}$ & China & $\begin{array}{l}\text { Habib et al. } \\
2017 b\end{array}$ \\
\hline $\begin{array}{l}\text { Melghiribacillus } \\
\text { thermohalophilus gen. } \\
\text { nov. }\end{array}$ & $\operatorname{Nari}_{2} A^{T}$ & Filamentous & $\begin{array}{lr}\text { Algerian } & \text { salt } \\
\text { lake, } & \text { Chott } \\
\text { Melghir } & \end{array}$ & Algeria & $\begin{array}{l}\text { Addou et al. } \\
\quad 2015\end{array}$ \\
\hline $\begin{array}{l}\text { Novibacillus } \\
\text { thermophilus gen. nov., } \\
\text { sp. nov. }\end{array}$ & $\begin{array}{l}\mathrm{SG}-1^{\mathrm{T}} \text { and } \\
\mathrm{SG}-2^{\mathrm{T}}\end{array}$ & $\begin{array}{l}\text { Facultative } \\
\text { anaerobe }\end{array}$ & $\begin{array}{l}\text { Saline } \quad \text { soil } \\
\text { sample } \\
\text { Compost } \\
\text { sample } \\
\end{array}$ & China & $\begin{array}{l}\text { Yang et al. } \\
\quad 2015\end{array}$ \\
\hline $\begin{array}{l}\text { Petrothermobacter } \\
\text { organivorans gen. } \\
\text { nov., sp. nov. }\end{array}$ & $\mathrm{ANA}^{\mathrm{T}}$ & $\begin{array}{l}\text { Chemoheterotrop } \\
\text { hic, acetate- } \\
\text { oxidizing and } \\
\text { iron(III)-, } \\
\text { manganese(IV)-, } \\
\text { nitrate- and } \\
\text { sulfate-reducing } \\
\text { bacterium }\end{array}$ & $\begin{array}{l}\text { Deep } \\
\text { subsurface oil } \\
\text { field }\end{array}$ & Japan & $\begin{array}{l}\text { Tamazawa } \\
\text { et al. } 2017\end{array}$ \\
\hline $\begin{array}{l}\text { Pseudogracilibacillus } \\
\text { endophyticus sp. nov. }\end{array}$ & DT7- $02^{\mathrm{T}}$ & $\begin{array}{l}\text { Form pinkish- } \\
\text { yellow, opaque, } \\
\text { glistering colony }\end{array}$ & $\begin{array}{l}\text { Root of } \\
\text { Oenotherabienn } \\
\text { is (evening } \\
\text { primrose) }\end{array}$ & $\begin{array}{l}\text { Republic } \\
\text { of Korea }\end{array}$ & $\begin{array}{l}\text { Park et al. } \\
2017\end{array}$ \\
\hline $\begin{array}{l}\text { Raineya orbicola gen. } \\
\text { nov., sp. nov }\end{array}$ & SPSPC- $11^{\mathrm{T}}$ & $\begin{array}{l}\text { Menaquinone } 7 \\
\text { present as major } \\
\text { quinone }\end{array}$ & Hot spring & Portugal & $\begin{array}{l}\text { Albuquerqu } \\
\text { e et al. } 2018\end{array}$ \\
\hline $\begin{array}{l}\text { Rubrobacter spartanus } \\
\text { sp. nov. }\end{array}$ & $\mathrm{GGR} 1^{\mathrm{T}}$ & $\begin{array}{l}\text { Cellulolytic, } \\
\text { anaerobe }\end{array}$ & $\begin{array}{l}\text { Soil, Caldera of } \\
\text { Kilauea Volcano }\end{array}$ & USA & $\begin{array}{l}\text { Norman et } \\
\text { al. } 2017\end{array}$ \\
\hline
\end{tabular}




\begin{tabular}{|c|c|c|c|c|c|}
\hline & & & $\begin{array}{l}\text { in Hawaii } \\
\text { Volcanoes } \\
\text { National Park } \\
\end{array}$ & & \\
\hline $\begin{array}{l}\text { Saccharopolyspora } \\
\text { subtropica sp. nov. }\end{array}$ & $\mathrm{T}^{\mathrm{T}}$ & $\begin{array}{l}\text { White aerial } \\
\text { mycelium and } \\
\text { colourless to pale } \\
\text { yellow } \\
\text { vegetative } \\
\text { mycelium }\end{array}$ & $\begin{array}{l}\text { Soil of a sugar } \\
\text { cane field }\end{array}$ & China & $\begin{array}{l}\text { Wu et al. } \\
2016\end{array}$ \\
\hline $\begin{array}{l}\text { Scopulibacillus } \\
\text { daqui sp. nov. }\end{array}$ & ZQ18-1 ${ }^{\mathrm{T}}$ & $\begin{array}{ll}\text { Central } & \text { oval } \\
\text { endospores } & \text { with } \\
\text { swollen } & \\
\text { sporangia } & \\
\end{array}$ & $\begin{array}{l}\text { Daqu sample, } \\
\text { Sesame-flavour } \\
\text { liquor-making } \\
\text { process }\end{array}$ & China & $\begin{array}{l}\text { Yao et al. } \\
2016\end{array}$ \\
\hline $\begin{array}{l}\text { Tepidibacillus } \\
\text { decaturensis sp. nov. }\end{array}$ & $Z 9^{\mathrm{T}}$ & $\begin{array}{l}\text { Iron-reducing } \\
\text { bacterium }\end{array}$ & $\begin{array}{l}\text { Mt. Simon } \\
\text { Sandstone of } \\
\text { the Illinois } \\
\text { Basin, Illinois } \\
\end{array}$ & USA & $\begin{array}{l}\text { Dong et al. } \\
2016\end{array}$ \\
\hline $\begin{array}{l}\text { Tepidibacillus } \\
\text { infernus sp. nov. }\end{array}$ & MBL-TLPT & $\begin{array}{l}\text { Selenate and } \\
\text { arsenate } \\
\text { respiring bacteri } \\
\text { um } \\
\end{array}$ & $\begin{array}{l}\text { TauTona gold } \\
\text { mine }\end{array}$ & $\begin{array}{l}\text { South } \\
\text { Africa }\end{array}$ & $\begin{array}{l}\text { Podosokorsk } \\
\text { aya et al. } \\
2016 \\
\end{array}$ \\
\hline $\begin{array}{l}\text { Thauera } \\
\text { hydrothermalis sp. nov. }\end{array}$ & GD- $2^{\mathrm{T}}$ & $\begin{array}{l}\text { Non-spore- } \\
\text { forming } \\
\text { bacterium }\end{array}$ & $\begin{array}{l}\text { Hot spring in } \\
\text { the } \quad \text { Tibet } \\
\text { Autonomous } \\
\text { Region }\end{array}$ & China & $\begin{array}{l}\text { Yang et al. } \\
\text { 2018a }\end{array}$ \\
\hline $\begin{array}{l}\text { Thermanaeromonas } \\
\text { burensis sp. nov. }\end{array}$ & IA $106^{\mathrm{T}}$ & $\begin{array}{l}\text { Thermophilic } \\
\text { halotolerant } \\
\text { strain }\end{array}$ & $\begin{array}{l}\text { Callovo- } \\
\text { Oxfordian clay } \\
\text { environment }\end{array}$ & France & $\begin{array}{l}\text { Gam et al. } \\
2016\end{array}$ \\
\hline $\begin{array}{l}\text { Thermoactinomyces } \\
\text { guangxiensis sp. Nov. }\end{array}$ & $\mathrm{CD}-1^{\mathrm{T}}$ & $\begin{array}{l}\text { Spherical- } \\
\text { polyhedron } \\
\text { endosphere with } \\
\text { smooth surface } \\
\end{array}$ & $\begin{array}{l}\text { Mushroom } \\
\text { compost }\end{array}$ & China & $\begin{array}{l}\text { Wu et al. } \\
2015\end{array}$ \\
\hline $\begin{array}{l}\text { Thermocrinis } \\
\text { jamiesonii sp. nov. }\end{array}$ & $\mathrm{GBS}^{\mathrm{T}}{ }^{\mathrm{T}}$ & $\begin{array}{l}\text { Chemolithotroph } \\
\text { ic, } \\
\text { microaerophilic } \\
\text { bacterium }\end{array}$ & $\begin{array}{l}\text { Water column } \\
\text { of Great Boiling } \\
\text { Spring, Nevada }\end{array}$ & USA & $\begin{array}{l}\text { Dodsworth } \\
\text { et al. } 2015\end{array}$ \\
\hline $\begin{array}{l}\text { Thermodesulfatator } \\
\text { autotrophicus sp. nov. }\end{array}$ & $\mathrm{S} 606^{\mathrm{T}}$ & $\begin{array}{l}\text { Sulfate-reducing } \\
\text { bacterium }\end{array}$ & $\begin{array}{l}\text { Sulfide sample, } \\
\text { deep-sea vent } \\
\text { chimney wall in } \\
\text { the Indian } \\
\text { Ocean }\end{array}$ & China & $\begin{array}{l}\text { Lai et al. } \\
2016\end{array}$ \\
\hline $\begin{array}{l}\text { Thermodesulfitimonas } \\
\text { autotrophica gen. nov., } \\
\text { sp. nov. }\end{array}$ & SF97 ${ }^{\mathrm{T}}$ & $\begin{array}{l}\text { Anaerobic, } \\
\text { chemolithoautotr } \\
\text { ophic bacterium }\end{array}$ & 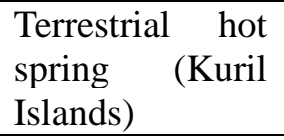 & Russia & $\begin{array}{l}\text { Slobodkina } \\
\text { et al. } 2017 \mathrm{~b}\end{array}$ \\
\hline $\begin{array}{l}\text { Thermostilla } \\
\text { marina gen. nov., sp. } \\
\text { nov. }\end{array}$ & $\mathrm{SVX}^{\mathrm{T}}$ & $\begin{array}{l}\text { Did not grow at } \\
\text { atmospheric } \\
\text { concentration of } \\
\text { oxygen but grew } \\
\text { microaerobically } \\
\text { (up to } 2 \% \\
\text { oxygen in the } \\
\text { gas phase) }\end{array}$ & $\begin{array}{l}\text { Shallow } \\
\text { submarine } \\
\text { hydrothermal } \\
\text { vent, Vulcano } \\
\text { Island }\end{array}$ & Italy & $\begin{array}{l}\text { Slobodkina } \\
\text { et al. 2016b }\end{array}$ \\
\hline
\end{tabular}




\begin{tabular}{|c|c|c|c|c|c|}
\hline $\begin{array}{l}\text { Thermosulfuriphilus } \\
\text { ammonigenes gen. } \\
\text { nov., sp. nov. }\end{array}$ & ST65 ${ }^{\mathrm{T}}$ & $\begin{array}{l}\text { Ammonification } \\
\text { of nitrate }\end{array}$ & $\begin{array}{l}\text { Deep-sea } \\
\text { hydrothermal } \\
\text { vent chimney, } \\
\text { Eastern Lau } \\
\text { Spreading } \\
\text { Centre, south- } \\
\text { western Pacific } \\
\text { Ocean }\end{array}$ & Russia & $\begin{array}{l}\text { Slobodkina } \\
\text { et al. } 2017 \mathrm{a}\end{array}$ \\
\hline $\begin{array}{l}\text { Thermus caldifontis sp. } \\
\text { nov. }\end{array}$ & $\begin{array}{c}\text { YIM } \\
73026^{\mathrm{T}}\end{array}$ & $\begin{array}{l}\text { Yellow colored } \\
\text { colonies }\end{array}$ & $\begin{array}{l}\text { Hot spring in } \\
\text { Tibet }\end{array}$ & China & $\begin{array}{l}\text { Khan et al. } \\
2017 \mathrm{a}\end{array}$ \\
\hline $\begin{array}{l}\text { Thermus sediminis sp. } \\
\text { nov. }\end{array}$ & $\begin{array}{l}\mathrm{L} 198^{\mathrm{T}} \text { and } \\
\mathrm{L}_{2} 23^{\mathrm{T}}\end{array}$ & $\begin{array}{l}\text { Ability to } \\
\text { oxidize } \\
\text { thiosulfate and } \\
\text { reduce arsenate }\end{array}$ & $\begin{array}{l}\text { Little Hot } \\
\text { Creek, the Long } \\
\text { Valley Caldera }\end{array}$ & California & $\begin{array}{l}\text { Zhou et al. } \\
\quad 2018\end{array}$ \\
\hline $\begin{array}{l}\text { Tibeticola } \\
\text { sediminis gen. nov., sp. } \\
\text { nov. }\end{array}$ & $\begin{array}{c}\text { YIM } \\
73013^{\mathrm{T}} \text { and } \\
\text { YIM } \\
73008^{\mathrm{T}}\end{array}$ & $\begin{array}{l}\text { Possesses polar } \\
\text { flagellum }\end{array}$ & $\begin{array}{l}\text { Hot spring in } \\
\text { Tibet, western } \\
\text { Tibet province }\end{array}$ & China & $\begin{array}{l}\text { Khan et al } \\
2017 b\end{array}$ \\
\hline \multirow{2}{*}{$\begin{array}{l}\text { Thermogutta terrifontis } \\
\text { gen. nov., sp. nov. } \\
\text { Thermogutta hypogea } \\
\text { sp. nov. }\end{array}$} & $\mathrm{R} 1^{\mathrm{T}}$ & \multirow{2}{*}{$\begin{array}{l}\text { Anaerobic } \\
\text { representatives } \\
\text { of the } \\
\text { phylum Plancto } \\
\text { mycetes }\end{array}$} & $\begin{array}{l}\text { Hot spring, } \\
\text { Kunashir Island }\end{array}$ & Russia & \multirow{2}{*}{$\begin{array}{l}\text { Slobodkina } \\
\text { et al. } 2015\end{array}$} \\
\hline & $\mathrm{SBP} 2^{\mathrm{T}}$ & & Deep gold mine & $\begin{array}{l}\text { South } \\
\text { Africa }\end{array}$ & \\
\hline
\end{tabular}

Currently the world has high demand for high value and low cost, and vice versa, organic products obtained from renewable, economic and readily available biomass. Biomolecules in bulk quantities and fine chemicals are produced in industries but the use of thermophiles is quite scarce. Thermozymes have important roles in bioconversion of raw materials or biomass into products.

Thermophiles are employed in numerous processes. Operationally stable thermophiles and thermozymes are useful in industrial processes which benefit of their functions and unique properties. Besides, high temperature processes offer process improvement, for instance, mixing, increases substrate solubility and high biomass transfer rate with a negligible risk of contamination (Gopinath et al. 2015). They have a wide number of applications on various industries and processes viz. detergent, textiles, leather industry, polymerase chain reaction (PCR), ligase chain reaction (LCR), diagnostics, food, paper and pulp, dairy products, baking, brewing, amino acid production, sugar mills, acrylamide production, starch processing, fat hydrolysis, chemical synthesis, esterification, organic biosynthesis, paper bleaching, pharmaceutical, molecular sieves, surfactants for oil recovery, bioinoculants, waste treatment, textile dye treatment, bio-energy generation/biofuels, biofilters, breast cancer treatment, bioconversion, bioremediation, hygiene indicator, for crude oil degradation, heavy metal recovery (Fig.2) and combination of former processes. In this research review, current developments and potential applications of thermophiles and thermozymes from bacteria and fungi were discussed. This review will provide with critical notions about potential thermophilic products and assists to build new future perspectives looking into a new biotechnological revolution.

\section{Prokaryotes and eukaryotes as cell factories for thermostable biocatalysts}

Today's World demands huge amounts of renewable and cheap biomass as a primary source for production of a wide variety of chemicals including fine, low-scale and high-value products, as well as bulk quantities of high-scale and low-value building blocks to be used in 
biotechnology and chemical processes. These can be produced in biorefineries using sustainable bioprocesses. Now a day prokaryotic and eukaryotic microbial cells factories are employed for bioconversion of biologically originated mass into desired products. A number of bioprocesses require either whole microbial cell or its byproducts in the form of enzymes which are operationally stable at high temperature (Table 2). Therefore, processes carried out at high temperature address risk of contamination and minimize contaminants, besides high temperature process offer better substrate solubility, ensue an environment-friendly industry, facilitating mixing and substrate availability and enhance high biomass transfer and bioconversion rate. Thus, thermophilic microorganisms have attracted the microbiologist and biotechnologist due to their enormous potential and stability at high temperatures. Few thermophilic microorganisms have been so far used and a few cells have been reported as ideal for biotechnological processes as raw models with broad applicability in research and industrial processes. They would have use as genetic tools, source and finger prints of novel molecules, primary gene sequence, and functional traits, to be major players in the protein engineering field (Verma and Kanwar 2012; Ang et al. 2018; Frenzel et al. 2018). Thermophiles have repeatedly been proposed as sources of industrially relevant thermostable enzymes (Schuerg et al. 2017). For example, the hyperthermophilic bacterium Thermotoga maritima MSB8 produces nitrilase (optimum temp. $45{ }^{\circ} \mathrm{C}$ and $\mathrm{pH} 7.5$ ). The nitrilase gene consists of 804 nucleotides encoding a protein of 268 amino acidic residues with a molecular mass of 30.07 kilodaltons (kDa) after sodium dodecyl sulfate (SDS)-polyacrylamide gel electrophoresis (PAGE) analysis. The nitrilase has been found to be a potential candidate for industrial applications on the biosynthesis of carboxylic acids (Chen et al. 2015). On other hand, novel eukaryotic thermostable DNA polymerases ( $\mathrm{dPol}$ ) have been developed for the rapid detection of Mycoplasma, Ureaplasma other bacteria and pathogenic fungi in amniotic fluid (Ueno et al. 2015; Venev and Zeldovich 2017).

Table 2. Industrial applications of thermostable enzymes in biotechnological processes

\begin{tabular}{|c|c|c|c|}
\hline $\begin{array}{c}\text { Thermostable } \\
\text { enzymes/ Product }\end{array}$ & Species & Industrial applications & Reference \\
\hline Acid Proteases & Brevibacillus spp. OA30 & $\begin{array}{l}\text { Production of bioactive } \\
\text { peptides from casein }\end{array}$ & $\begin{array}{l}\text { Guinane et al. } \\
\text { 2015; Gomri et al. } \\
2018\end{array}$ \\
\hline Alkaline Proteases & $\begin{array}{lr}\text { Bacillus } & \text { subtilis } \text { Y-108, } \\
\text { Bacillus } & \text { licheniformis, } \\
\text { Brevibacillus } \text { spp. }\end{array}$ & Detergent industries & $\begin{array}{c}\text { Ramkumar et al. } \\
\text { 2018; Barzkar et } \\
\text { al. } 2018\end{array}$ \\
\hline $\begin{array}{l}\text { Amyloglucosidase, } \\
\text { Glycosyltransferase, } \\
\text { Glycoside hydrolase } \\
\text { and } \\
\text { Transglycosylase, } \\
\text { Pullulanse, } \\
\text { Glucanases }\end{array}$ & $\begin{array}{l}\text { Thermus thermophilus, } \\
\text { Thermus scotoductos, } \\
\text { Bacillus stearothermophilus, } \\
\text { Alkalophilc Bacillus sp.I-5, } \\
\text { Rhodothermus obamensis, } \\
\text { Neisseria polysaccharea, } \\
\text { Deinococcus geothermalis, } \\
\text { Bacillus stearothermphilus, } \\
\text { Thermus spp., }\end{array}$ & Food and baking industry & $\begin{array}{l}\text { Singh et al. 2016; } \\
\text { Do et al. 2016; } \\
\text { Baroroh et al. } \\
\text { 2017; Park et al. } \\
2018\end{array}$ \\
\hline$\alpha$-Amylase & Bacillus licheniformis & $\begin{array}{l}\text { Industrial applications in } \\
\text { unconventional and } \\
\text { economical substrate viz. } \\
\text { waste management } \\
\text { problem of agro-industrial }\end{array}$ & $\begin{array}{l}\text { Rekadwad and } \\
\text { Pathak 2016; } \\
\text { Awan et al. } 2018\end{array}$ \\
\hline
\end{tabular}




\begin{tabular}{|c|c|c|c|}
\hline & & waste of potato peels & \\
\hline$\beta$-Amylase & Bacillus spp., Apergillus spp. & $\begin{array}{l}\text { Starch degrading sector, } \\
\text { food processing factories }\end{array}$ & $\begin{array}{c}\text { Banerjee and Ray } \\
2017\end{array}$ \\
\hline $\begin{array}{l}\text { Cellulases, } \\
\text { Endoglucanases, } \beta \text { - } \\
\text { glucosidase, } \\
\text { cellodextrinases }\end{array}$ & $\begin{array}{l}\text { Bacillus amyloliquefaciens, } \\
\text { Aspergillus nidulans, } \\
\text { Cellulosimicrobium funkei, } \\
\text { Xylanimicrobium pachnodae, } \\
\begin{array}{l}\text { Humicola grisea var. } \\
\text { thermoidea }\end{array}\end{array}$ & $\begin{array}{l}\text { Biostoning, To release } \\
\text { aromatic compounds from } \\
\text { fruit and fermentation, } \\
\text { Juice clarification, } \\
\text { Pharmaceutical industry }\end{array}$ & $\begin{array}{l}\text { Escuder- } \\
\text { Rodríguez et al. } \\
2018\end{array}$ \\
\hline Hemicellulases & $\begin{array}{l}\text { Aspergillus fumigatus JCM } \\
10253\end{array}$ & Biofuel industries & Saroj et al. 2018 \\
\hline Inulinase & \begin{tabular}{lrr} 
Kluyveromyces & \multicolumn{2}{c}{ marxianus, } \\
Cryptococcus & aureus $\mathrm{G7a}$, \\
Bacillus & smithii $\mathrm{T} 7$, \\
Aspergillus & awamori, \\
Arthrobacter & sp. & S37, \\
Streptomyces & rochei & E87, \\
Xanthomonas spp. & \\
\end{tabular} & $\begin{array}{l}\text { Biorefining, higher value- } \\
\text { added production }\end{array}$ & $\begin{array}{l}\text { Qui et al. 2017; } \\
\text { Bhagia et al. } \\
\text { 2017; Khatun et } \\
\text { al. 2017; Qiu et al. } \\
\text { 2017 }\end{array}$ \\
\hline $\begin{array}{l}\text { Invertase or } \\
\beta \text {-D-fructofuranosid } \\
\text { e fructohydrolase }\end{array}$ & $\begin{array}{l}\text { Bacillus cereus, } \\
\text { Bifidobacterium adolescentis } \\
\text { G1, Lactobacillus reuteri } \\
\text { CRL, Thermotoga } \\
\text { neapolitana DSM 4359T, } \\
\text { Arthrobacter globiformis IFO } \\
\text { 3062, Lactobacillus brevis } \\
\text { Mm-6, Zymomonas mobilis } \\
\text { CDBB-B603 }\end{array}$ & $\begin{array}{l}\text { Functional food with } \\
\text { prebiotic ingredients }\end{array}$ & $\begin{array}{l}\text { Lincoln and More } \\
2017\end{array}$ \\
\hline Lactase & $\begin{array}{l}\text { Aspergillus oryzae, } \\
\text { Aspergillus niger, Aspergillus } \\
\text { sphaericus, Kluyveromyces, } \\
\text { Streptococcus spp. }\end{array}$ & Food Industry & Grace et al. 2017 \\
\hline Lipases & $\begin{array}{l}\text { Thermoanaerobacter } \\
\text { thermohydrosulfuricus (LipTt } \\
\text { h) and Caldanaerobacter } \\
\text { subterraneus subsp. tengcong } \\
\text { ensis (LipCst) }\end{array}$ & $\begin{array}{l}\text { Highly } S \text {-stereoselective } \\
\text { toward esters of secondary } \\
\text { alcohols. Kinetic resolution } \\
\text { of synthetically useful } \\
\text { compounds. }\end{array}$ & $\begin{array}{l}\text { Royter et al. 2009; } \\
\text { Widowati et al. } \\
\text { 2017; Rigoldi et } \\
\text { al. } 2018\end{array}$ \\
\hline Neutral Proteases & Aspergillus oryzae $\mathrm{Y} 1$ & $\begin{array}{l}\text { Pea sauce production in the } \\
\text { food processing industry }\end{array}$ & Ao et al. 2018 \\
\hline $\begin{array}{l}\text { Pectinases/ } \\
\text { Polygalactouronase }\end{array}$ & $\begin{array}{l}\text { Aspergillus niger, } \\
\text { Chryseobacterium } \\
\text { indologenes strain SD, Citrus } \\
\text { nobilis var. chrysocarpa }\end{array}$ & $\begin{array}{l}\text { Fruit processing, Fruit } \\
\text { juice clarification }\end{array}$ & $\begin{array}{l}\text { Sandri and da } \\
\text { Silveira, 2018; } \\
\text { Roy et al. } 2018\end{array}$ \\
\hline S-Layers proteins & S. acidocaldarius, S. marinus & $\begin{array}{l}\text { Gold }(\mathrm{Au}) \text { nanoparticle } \\
\text { production, As a drug } \\
\text { delivery system }\end{array}$ & $\begin{array}{c}\text { Rodrigues- } \\
\text { Oliveira et al. } \\
\text { 2017; } \\
\text { Pohlschroder et al. } \\
\text { 2018; Khursigara } \\
\text { et al. } 2018 \\
\end{array}$ \\
\hline $\begin{array}{l}\text { Taq DNA } \\
\text { Polymerase }\end{array}$ & $\begin{array}{l}\text { Thermus aquaticus YT-1, } \\
\text { Thermus brockianus GE-1, }\end{array}$ & $\begin{array}{l}\text { Possesses } \text { a } 5^{\prime} \rightarrow 3^{\prime} \\
\text { polymerase activity and a } \\
5^{\prime} \quad \text { flap endonuclease }\end{array}$ & $\begin{array}{l}\text { Krefft et al. 2017; } \\
\text { Sundarrajan et al. } \\
2018\end{array}$ \\
\hline
\end{tabular}




\begin{tabular}{|l|l|l|l|}
\hline & & $\begin{array}{l}\text { activity. Primarily used in } \\
\text { DNA fragment extension } \\
\text { reactions popularly known } \\
\text { as polymerase chain } \\
\text { reaction (PCR) }\end{array}$ \\
\hline Thiol proteases & $\begin{array}{l}\text { Bacillus subtilis AKAL7, } \\
\text { Exiguobacterium indicum } \\
\text { AKAL11 }\end{array}$ & $\begin{array}{l}\text { In leather industry for de- } \\
\text { hairing of skin }\end{array}$ & Hakim et al. 2018 \\
\hline
\end{tabular}

\section{Biorefineries for production of commodity chemicals using renewable resource}

The development of microbial products in biorefineries and their use for the sustainable biotechnology is also influenced by ethical, political and economical concerns (Boldrin et al. 2013; Glaser et al. 2018; Puentes-Téllez and Salles 2018). Overcoming exceptions to these drawbacks, in near future, thermostable enzymes and thermophiles are highly relevant for the required advancements demanded by modern biotechnological industry for the benefits of mankind and society especially in developing countries.

The use of enzymes, or natural biocatalysts, transformations of purely chemical processes into biochemical processes in a sustainable way is the aim of White Biotechnology. Thermostable enzymes used in various bioprocesses (Zarafeta et al. 2016a,b,c; Quehenberger et al. 2017; Liang et al. 2018) and biorefineries are important start-ups and currently highlighted ways to produce renewable raw materials, industrially important intermediates and final products having low volume with high value and vice versa (Fig.3) in the "White Biotechnology" revolution. Broadly, thermophiles are potential major players in modern biotechnology. Expansion of the unimaginable power of enzymes, and specifically those from thermophiles, to synthesize products that are stable, useful, effortlessly degradable with utilization of minimal energy and generation of wastes (Frazzetto 2003; Fernandez-Cabezon et al. 2018) using recyclable and sustainable raw materials (i.e., biomass). Through the use of biorefineries, at present, it is possible to convert feedstocks into commercially useful biological products (Ferraz Júnior et al. 2016; Guo et al. 2017; Huang et al. 2017; Chandel et al. 2018; David et al. 2018 ). Therefore, metabolically active thermophiles are very important for biocatalytic conversions of raw materials in utilizable forms for the generation of metabolizable building blocks (such as sugars from polymers) and desired products through oxidations, reductions, hydrolysis, carbon-carbon bond formations and enzyme catalysis. For instance, hydroxylation Baeyer-Villiger oxidation reactions carried out by monooxygenases (Kadowaki et al. 2018), alcohol dehydrogenases produced by thermophiles through stereoselective reduction of carbonyl compounds to chiral alcohols (Vitale et al. 2018), toxic chemicals could be replaced by lipases or oxido-reductases through epoxide synthesis (Jia et al. 2017), lyases can form C-C bonds, thermostable transferases and glycoside hydrolases catalyze glycoside synthesis through reverse hydrolysis and produce products such as glycooligosaccharides, glycol-conjugate alkyl-glycosides (Rockova et al. 2012; Schröder et al. 2017; Watanabe et al. 2018; Diwan et al. 2018; Dreger et al. 2018). The use of immobilized whole cells and enzymes in biorefineries increases production of useful building blocks/materials and metabolic products (Akita et al. 2018). Thermostable enzymes must reach high production levels at low cost and high efficiency to achieve highly competitive bioprocesses. 


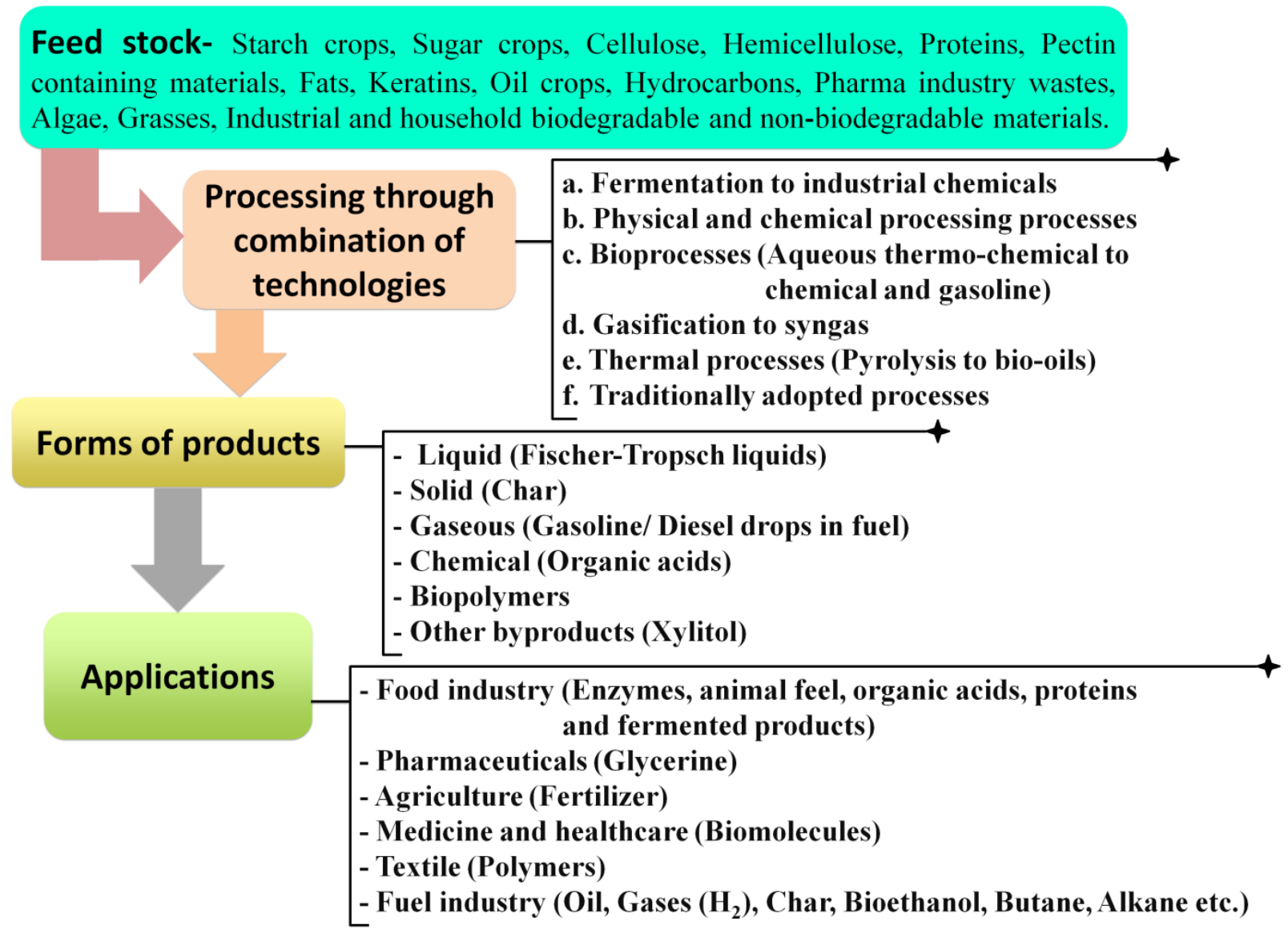

Fig. 3 Overview of biorefineries: Multidisciplinary involvement and potential applications for thermophiles

\section{Second generation ethanol production}

A typical example of the use of biomass in biotechnology is the production of bioethanol and, in general, biofuels. Bioethanol production has been significantly improved with the establishment of the second generation processes which enhanced sugar utilization using genetically engineered yeasts. Nevertheless, common pre-treatments of plant residues and biomass include high temperature incubations which suggests the need for thermophiles and their highly thermoestable enzymes. Thermophiles are used for the production of biofuel (bioethanol) i.e. non-native alcohols. Bioethanols are produced from complex lignocellulosic biomass due to their higher operating temperatures and broad substrate range which facilitates mixing, substrate accessibility and degradability. High temperature is a critical factor dealt with processing highly viscous syrups obtained from vegetal biomass which can used as raw material in later steps (Strang et al. 2017). Later steps of ethanonol production can be carried out using aerobic bacteria and yeasts and anaerobic bacteria. Herein we have the focus on the main orders of anaerobic thermophiles, for example, Thermoanaerobacterales known to produce ethanol (Zheng et al. 2018). Physiology and relevance of various environmental factors, including the partial pressure of hydrogen, ethanol tolerance, $\mathrm{pH}$ and substrate inhibition, allows full growth of Thermoanaerobacterales under anaerobic conditions lead to increased ethanol yields (Scully et al. 2015; Zheng et al. 2018). Moreover, evolutionary adaptation and recent development in genetic engineering of Thermoanaerobacterales would be helpful in batch or simultaneous saccharification, fermentation and consolidated bio-processing (Jia et al. 2017; Basit et al. 2018a, b; Sitthikitpanya et al. 2018). 


\section{Thermostable biomolecules and their potential applications}

\section{Lignocellulose degrading extremozymes}

Lignocellulosic biomass is important to manufacture renewable and biodegradable byproducts (Botha et al. 2018). Extremophilic lignocellulosic enzymes especially betamannanases, xylanases, laccases and cellulases, including endo-glucanases, exo-glucanases and beta-glucosidases have potential applications in biotechnology in near future (Ergun and Calik 2016). Many of these enzymes were genetically engineered into Pichia pastoris. These genetically engineered extremozymes are superior enzymes with improved stability due to proper post-translational modifications leading to better protein folding. This change in production apparatus shows that the host (Pichia pastoris) is highly favored system for production of extremozymes (Gidijala et al. 2018).

Exceptionally, biological process of glycosylation contributes to the structure, stability and function of enzymes (Tian et al. 2018; Ge et al. 2018) expressed in P. pastoris and exhibit better thermostability over other non-glycosylated (Yang and Zhang 2018b). In this particular case, there were few reviews on chemical design to enhance synergistic proficient ensuring lignocellulosic proteins. Later studies performed using computational approach with a focus on enzyme activity shows less dependability, enhanced reactivity and high productivity by enzyme is only due to structural changes in catalysts that may leads to significant process modernization (David et al. 2018; Malla et al. 2018). However, there are limited reports available on enzyme engineering to improve catalytic efficiency and stability of lignocellulosic thermoenzymes. Therefore, data generated from metagenomics analysis would be utilized for exploitation and discovery novel enzymes (Kuancha et al. 2017). Thus, in near future, studies should have focus on protein engineering based on stable natural models, mainly from thermophilic microorganisms, to improve stability and catalytic efficiency using modern approaches. Taxonomists, molecular microbiologists and genetic engineers should continue search and have thrust to find new metabolic pathways, natural processes in existing microorganisms using metagenomics, metatranscriptomics (Rekadwad and Ghosh 2018; Rekadwad, 2018a,b,c), computational modeling, mutations, domain replacements and fusion enzyme technology (Lee et al. 2018) approach to perform specific processes for the goal to be achieved.

Another study of biomass degradation is the examples of a cellulase and two esterases from environmental Geobacillus strains obtained from metagenomic sequence data. These enzymes degrade lignocellulosic materials, optimally between $40^{\circ} \mathrm{C}$ and $70^{\circ} \mathrm{C}$, and, interestingly, they showed an increase in activity when supplemented with barium $\left(\mathrm{BaCl}_{2}\right)$ (Muñoz et al. 2016).

\section{Thermostable esterases}

Thermostable esterase (Estgela) produced by a moderate thermophile Bacillus gelatini strain KACC 12197KA (Kim et al. 2015). Esterases encoding genes were also found in the Thermus filiformis (Mandelli et al. 2017). Estgela enzyme (a novel thermostable esterase from Bacillus gelatini KACC 12197 (Kim et al. 2015) (molar mass 42 kDA) contains 389 amino acids. The BLASTx results of Estgela shows similarity with $\beta$-lactamases and esterases (43\%). The cloned SerXXLys conserved sequence (Ser58Met59Thr60Lys61) of Estgela gene in Escherichia coli XL1blue showed a remarkable enzymatic activity toward $p$ nitrophenyl-ester with short four carbon acyl-chains and the strongest activity towards $p$ nitrophenyl-butyrate (Kim et al., 2015a). Estgela shows maximum activity at $65-75{ }^{\circ} \mathrm{C}$ and 180 min after incubation at $65{ }^{\circ} \mathrm{C}$ retained more than $90 \%$ of the initial activity. Furthermore, Estgela showed the maximal activity at $\mathrm{pH} 10$. Surfactants were effectively improved the 
enzymatic activity of Estgela (Antonopoulou et al. 2018). Estgela was capable to hydrolyze (both $R$ and $S$ ) ketoprofen-ethyl-ester with enantio-selectivity toward $(S)$-ketoprofen-ethylester rather than $(R)$-ketoprofen-ethyl-ester which represents a significant improvement because of the role of these compounds in the degradation of biomass and industrial pollutants (Mäkelä et al. 2018; Romero et al. 2018). Moreover, esterases are also useful in the synthesis of optically pure compounds, perfume, and antioxidants (Mandelli et al. 2017; Botha et al. 2018).

\section{Potential applications of keratinases}

Keratin is cosmopolitan in natural fibre. Animal body parts such as hair, nails, hoofs, feathers and horns are recalcitrant structural proteins with high number of disulfide bridges (Middelveen et al. 2018; Navone and Speight 2018). Keratinases are proteolytic enzymes that attack disulfide bridges of keratin. Therefore, keratinases are useful in preparation of animal nutrients, textile processing, leather manufacture, detergent formulation, protein supplements, the pharmaceutical and biomedical industries, feather meal processing for feed and as fertilizers, and waste management (Barman et al. 2017; Banerjee and Ray 2017; Verma et al. 2017; Hakim et al. 2018).

Generally, keratinases are produced in batch culture (Drejer et al. 2018). It is necessary to produce keratinase from economic raw sources using microorganisms (Reddy et al. 2017). Saloons, abattoir and mundan (donating hair) at sacred places are best sources for raw keratin. This bulk keratin could be exploited for the production of microbial keratinases obtained from Fungi, Bacteria, and primarily Actinomycetes. These microbial keratiinases are less expensive than conventionally produced keratinases.

\section{Keratinolytic thermophilic fungi}

Few reports are available in recent days on keratinolytic thermophilic fungi. Keratinolytic thermophilic fungi are capable of producing keratinases from keratincontaining waste materials (Kanoksilapatham and Intagun 2017; Zhang et al. 2018). Applications of keratin degrading thermophilic fungi could be deduced based on studies on moderately thermophilic or mesophilic keratinolytic fungi showing their potential. A number of keratinolytic fungi utilize native keratin as a sole carbon (C) and nitrogen (N) source for their growth and multiplication. The keratinophilic fungi of group Hyphomycetes include both dermatophytic (e.g., Microsporum, Epidermophyton, and Trichophyton) and nondermatophytic (e.g., Chrysosporium and other genera) keratinophilic fungi (Suaria et al. 2018). Keratinolytic thermophilic fungi were abundant in soils nearer to Earth's equator and up to tropics. They shows high abundance in waste keratin samples in some areas such as public gardens $(65 \%)$, waste from schools and saloons $(52 \%)$, poultry farms $(43 \%)$, garbage (34\%), hospitals (30\%) and rivers $(21 \%)$. It is reported that keratinophilic fungi are dominant in areas inhabited by humans and animals (Saggu and Mishra 2017).

Keratinophilic Fungi produce sulfide through sulphitolysis and, during this process, the disulfide bonds of cysteine, a major amino acid in keratinous materials, are broken down, after which the proteolytic enzymes released by the fungi that can easily cleave the keratin. During the degradation process, the products released are cysteine, S-sulphocysteine and inorganic sulfate, and the presence of these products in the culture media indicates the occurrence of true keratinophilic Fungi (Zhang et al. 2018). For wide applicability of keratinophilic fungi in biotechnology, modification in disulfide bridges and addition of covalent bonds would be an appropriate solution for improvement in thermostability of keratinophilic fungi. 


\section{Keratin-degrading bacteria}

Thermophilic bacteria have advantages over fungi because of fast growth rate and inherent characteristic possessed by them. Among the keratinase producing thermophilic bacteria some belonging to Gram positive bacteria include Bacillus subtilis, B. licheniformis, (Abdel-Fattah et al. 2018; Singh et al. 2018; Dreger et al. 2018), Burkholderia (Huang et al. 2018), Lysobacter (Laba et al. 2018), Nesterenkonia, Kocuria, and Microbacterium (Nouioui al. 2018) and Gram-negative bacteria include Chryseobacterium (Navone et al. 2018), Fervidobacterium, Stenotrophomonas (Wang et al. 2017), Thermoanaerobacter, Xanthomonas, Nesterenkonia and Vibrio (Laba et al. 2018). Moreover, Actinomycetes, Streptomyces group, namely, S. fradiae, Streptomyces species A11, S. pactum, S. albidoflavus, S. thermoviolaceus SD8, and $S$. graminofaciens, as well as hermoactinomyces candidus, were capable of producing keratinase (Nouioui et al. 2018).

An example to search for keratinases from hyperthermophilic bacteria is the genus Fervidobacterium (Thermotogae). Some species of this genus are capable of completely degrade feathers in cultures, suggesting highly keratinase activity within this genus (Kanoksilapatham et al. 2016).

\section{Thermophilic dihydroxyacetone phosphate (DHAP)-dependent aldolases}

The potential of aldolases contributes to the development of greener and sustainable processes because they contribute to the decomposition of sugars both actually breaking down the sugar molecule into smaller components, as well as activating subsequent metabolic pathways which can potentially enhance biotechnological processes. Four different kinds of structurally characterized DHAP-dependent aldolases were described up to now. Only few aldolases have been studied for stereo-selectivity although they may not be commercially available yet. Thermostable aldolases may contribute and eliminate current limitations of aldolases viz. poor product yields or short half-life span encountered with previous DHAPdependent aldolases. Of these Fructose 1, 6-bisphosphate (FBP) aldolase (FBPA, EC 4.1.2.13) from (hyper)thermophilic have been intensively studied because of their physiological role(s) in glycolysis and gluconeogenesis (Falcicchio et al. 2014). The active system of biozyme Mja-FucA may advance the development of a robust model for carboncarbon (C-C) coupling at extremely high temperature to test (hyper)thermostable biozyme in sensitive field of hilter kilter combination (i.e. asymmetric synthesis). To avert dihydroxyacetone phosphate (DHAP) in system involving water, synthesis in natural polar and nonpolar organic solvents might be an answer (Puckett et al. 2014; Hartley et al. 2017; Visone et al. 2017; Mohammad et al. 2017; Yokoyama et al. 2018). In any case, this method has been so far ineffectively explored in both mesophilic and thermophilic proteins, because DHAP are pernicious for biochemicals. (Hyper)thermophiles could have an ability to enhance the productivity under hardish conditions and at uplifted temperatures (Falcicchio et al. 2014). Downstream process of these products at high temperature may help to improve amalgamation and partition of product(s). On other hand, imperative catalysts from (hyper)thermophiles that would built biocatalytic variants. (Hyper)hermophilic DHAPsubordinate aldolases are less stereoselective than mesophilic ones (Joseph et al. 2018).

Apparently, lack of stereoselectivity aligned with the extreme stability of many (hyper)thermostable enzymes may be a solution to develop versatile and robust biocatalysts stable at high temepratures.

\section{Acetogenesis by thermophilic anaerobes}

Anaerobic bacteria produce acetate through Wood-Ljungdahl pathway from carbon dioxide and a source of electron such as hydrogen, carbon monoxide, formate etc. This 
process is call acetogenesis. The process of acetogenesis carried out by thermophilic bacteria, is termed 'Hot Acetogenesis'.

Only a few acetogenic bacteria within the thermophiles have been reported. Members of the family Thermoanaerobacteraceae such as Moorella spp., Thermoanaerobacter kivui and Thermacetogenium phaeum conserve energy from hot acetogenesis. These organisms possess potential biochemical pathways for energy recovery from greenhouse gas (i.e., $\mathrm{CO}_{2}$ ) under anaerobic conditions (Basen and Müller 2017; Ma et al. 2019). This would be a potential alternative energy strategy for conservation energy because acetate is a major intermediate, for instance, during bio-fuel producing processes.

\section{Biodegradation of polycyclic aromatic hydrocarbons (PAHs)}

Extremophiles, including thermophiles, also have ability to colonize surfaces and deep subsurfaces in extreme environments such as hydrocarbon polluted sites and petroleum reservoirs (Sierra-Garcia et al. 2017). These reservoirs are rich in PAHs. PAHs are environmental pollutants showing deleterious effects to biodiversity and ecosystem health. Extremophilic microorganisms and specially thermophiles and halophiles possess known established mechanisms for the biodegradation of PAHs through environmentally friendly pathways. The bacterium Stenotrophomonas maltophilia strain AJH1, Bordetella avium, Desulfomicrobium and many other strains are capable of degrading low molecular weight and high molecular weight PAHs. One constraint about PAH degradation is to achieve adequate PAH dissolution. By doing high temperature processes, PAH dissolution is increased and this could represent a great opportunity to use thermophiles to obtain higher PAH degradation efficiencies. Thus, the use of thermophiles and other extremophiles for the treatment of hydrocarbon polluted industrial waters and oil spills would be a novel and environmentally friendly technology (Arulazhagan et al. 2017; Wolfson et al. 2018; Abo-State et al. 2018; Marozava et al. 2018).

\section{Biotechnological applications of mobile group II introns (MGIs)/Targetrons (TTNs)}

Versatile MGIs are bacterial retrotransposons. They have capacity to recognize base pairing in DNA target sites, catalyze the reaction, achieve high DNA target specificity and couple correct base pairing (Mohr et al. 2010; Mohr et al. 2013). These targetrons have vast application viz. enable gene targeting and genetic engineering of bacteria. A thermostable targetron has been developed for use in thermophilic bacteria (Rekadwad et al. 2017; Baronti et al. 2018). Position for recombinase recognition sites enable large-scale genome-editing operations, such as insertions, deletions, inversions and translocation of large DNA segments can be developed using targetrons (Enyeart et al. 2014; Bou-Nader et al. 2018). MGI reverse transcriptases can yield large amounts of highly active proteins. These bacterial thermostable MGI reverse transcriptases are being used as research tools for a variety of applications such as qRT-PCR, new generation RNA sequencing, etc.

\section{Improvement in thermostability through mutation/s}

Enhancement of thermostability of moderate thermostable enzymes could be achieved through modification in enzyme structure (Vanz et al. 2012; Attri et al. 2018), specific covalent bond modification (Darby et al. 2017). For example, introduction of disulfide bridges and elimination of native biochemical bonds, generally, help to expand thermostability of enzyme. Esterases such as A-feruloyl-esterase (AuFaeA) produced by Aspergillus usamii (A. usamii) E001 were thoroughly studied for improvement of thermostability and applications in biotechnology. DSDBASE (http://caps.ncbs.res.in/dsdbase/dsdbase.html), MODIP (http://caps.ncbs.res.in/iws/modip.html) and DbD2 (http://cptweb.cpt.wayne.edu/DbD2/ (Yin 
et al. 2015a; Song et al. 2018) are the three computational tools that could give an idea about anticipated disulfide bridges in enzymes/or proteins. These databases can allow us to check possible improvement in thermostability of enzymes or proteins (Pezeshgi et al. 2018). Similarly, molecular dynamics (MD) simulations (e.g. AMBER, CP2K, CPMD, Gromacs, etc.,) were used to design potential disulfide bridges to be incorporated into proteins. Modifications such as increasing of disulfide bridges in proteins can be carried out by mutations one residue pair A126-N152 to cysteine and expressed in Pichia pastoris GS115 (Liu et al. 2016; Zhou et al. 2017). Moreover, incorporation of the local disulfide bridges in AuFaeA results in a great decrease in expression level by $10^{\circ} \mathrm{C}$ (Uraji et al. 2014; Yin et al. 2015b; Alvarez et al. 2016; Broeker et al. 2018). Therefore, improved and modified thermostable AuFaeA like variant may find applications in the enzymatic degradation of plant biomass materials at elevated temperatures.

\section{Conclusion}

Thermophiles and thermozymes are necessary due to their high activity and stability at high temperatures. They can reduce the cost of production of biomolecules from low-cost raw biomaterials. The cost-effective translation of substrate into useful products for commercial applications using prokaryotes and eukaryotes (i.e., biotransformations) steadily contributes and replaces traditional catalysts in chemical process. Thus, biotechnologically and commercially important high-value and low-volume and low value-high volume byproducts generated using thermophiles are useful in healthcare, medicine, agriculture and pharmaceuticals.

\section{Future perspectives}

This review discussed some examples of novel initiatives enhancing the potential of White biotechnology involving the use of thermophiles and thermozymes. New biomolecules and thermophiles are waiting to be discovered for their innovative application and an unimaginable power of genes for improving and strengthen biotechnological processes, some of which remain to be commercially applied. There is a need to design new procedures and protocols for the cultivation of novel thermophiles having applications in biotechnology, agriculture, medicine and healthcare. In addition, culture-independent techniques remain as a major source to retrieve novel enzyme-encoding genes of high biotechnological potential. In summary, the potential for applications of biocatalytic durables-thermostable enzymes-with expanded specificity and high efficiency has been shown for numerous thermophiles and thermozymes but their commercialization should be accelerated for society to profit today from current knowledge.

\section{Conflict of Interest}

All authors declare that they have no conflict of interest.

\section{Acknowledgement}

BR is thankful to the University Grants Commission, New Delhi (Ministry of Human Resource Development, The Government of India) for financial support (File No. PDFSS2013-14-ST-MAH-4350). JMG acknowledges funding from European program ERA-IB16049 and Spanish Ministry (PCIN-2016-129). 


\section{References}

Abdel-Fattah AM, El-Gamal MS, Ismail SA, Emran MA, Hashem AM (2018) Biodegradation of feather waste by keratinase produced from newly isolated Bacillus licheniformis ALW1. J Gent Eng Biotechnol. https://doi.org/10.1016/j.jgeb.2018.05.005

Abo-State MAM, Riadb BY, Bakr AA, Abdel Aziz MF (2018) Biodegradation of naphthalene by Bordetella avium isolated from petroleum refinery wastewater in Egypt and its pathway. J Radiat Res Appl Sci 11:1-9. https://doi.org/10.1016/j.jrras.2017.10.001

Addou N, Schumann P, Spröer C, Ben Hania W, Hacene H, Fauque G, Cayol J, Fardeau M (2015) Melghiribacillus thermohalophilus gen. nov., sp. nov., a novel filamentous, endospore-forming, thermophilic and halophilic bacterium. Int J Syst Evol Microbiol 65:1172-1179. http://doi.org/10.1099/ijs.0.000075

Akita H, Hayashi J, Sakuraba H, Ohshima T (2018) Artificial thermostable D-amino acid dehydrogenase: creation and application. Front Microbiol 9:1760. https://doi.org/10.3389/fmicb.2018.01760

Albuquerque L, Polónia A, Barroso C, Froufe H, Lage O, Lobo-da-Cunha A, Egas C, da Costa M (2018) Raineya orbicola gen. nov., sp. nov. a slightly thermophilic bacterium of the phylum Bacteroidetes and the description of Raineyaceae fam. nov. Int J Syst Evol Microbiol 68:982-989. http://doi.org/10.1099/ijsem.0.002556

Alvarez, C, Reyes-Sosa FM, Díez B (2016) Enzymatic hydrolysis of biomass from wood. Microb Biotechnol 9: 149-156. http://doi.org/10.1111/1751-7915.12346

Anders H, Power J, MacKenzie A, Lagutin K, Vyssotski M, Hanssen E, Moreau J, Stott M (2015) Limisphaera ngatamarikiensis gen. nov., sp. nov., a thermophilic, pinkpigmented coccus isolated from subaqueous mud of a geothermal hotspring. Int J Syst Evol Microbiol 65:1114-1121. http://doi.org/10.1099/ijs.0.000063

Ang TF, Maiangwa J, Salleh AB, Normi YM, Leow TC (2018) Dehalogenases: from improved performance to potential microbial dehalogenation applications. Molecules 23:1100. http://doi.org/10.3390/molecules23051100

Antonopoulou I, Dilokpimol A, Iancu L, Mäkelä MR, Varriale S, Cerullo G, Hüttner S, Uthoff S, Jütten P, Piechot A, Steinbüchel A, Olsson L, Faraco V, Hildén KS, de Vries RP, Rova U, Christakopoulos P (2018) The synthetic potential of fungal feruloyl esterases: a correlation with current classification systems and predicted structural properties. Catalysts 8:242. http://doi.org/10.3390/catal8060242

Ao XL, Yu X, Wu DT, Li C, Zhang T, Liu SL, Chen SJ, He L, Zhou K, Zou LK (2018) Purification and characterization of neutral protease from Aspergillus oryzae Y1 isolated from naturally fermented broad beans. AMB Express 8:96. https://doi.org/10.1186/s13568-018-0611-6

Arulazhagan P, Al-Shekri K, Huda Q, Godon JJ, Basahi JM, Jeyakumar D (2017) Biodegradation of polycyclic aromatic hydrocarbons by an acidophilic Stenotrophomonas maltophilia strain AJH1 isolated from a mineral mining site in Saudi Arabia. Extremophiles 21:163-174. https://doi.org/10.1007/s00792-016-0892-0

Attri P, Han J, Choi S, Choi EH, Bogaerts A, Lee W (2018) CAP modifies the structure of a model protein from thermophilic bacteria: mechanisms of CAP-mediated inactivation. Sci Rep 8:10218. http://doi.org/10.1038/s41598-018-28600-w

Awan K, Jabeen F, Manzoor M, Qazi JI (2018) Potential of thermophilic amylolytic bacteria for growth in unconventional media: potato peels. J Food Pro Eng 41:e12635. https://doi.org/10.1111/jfpe.12635

Banerjee G, Ray AK (2017) Impact of microbial proteases on biotechnological industries. Biotechnol Genet Eng Rev 33:119-143. http://doi.org/10.1080/02648725.2017.1408256

Barman NC, Zohora FT, Das KC, Mowla MG, Banu NA, Salimullah M, Hashem A (2017) Production, partial optimization and characterization of keratinase enzyme 
by Arthrobacter sp. NFH5 isolated from soil samples. AMB Express 7:181. http://doi.org/10.1186/s13568-017-0462-6

Baronti L, Karlsson H, Marušič M, Petzold K (2018) A guide to large-scale RNA sample preparation. Anal Bioanal Chem 410:3239-3252. http://doi.org/10.1007/s00216-0180943-8

Baroroh U, Yusuf M, Rachman D, Ishmayana S, Syamsunarno MRAA, Levita J, Subroto T (2017) The importance of surface-binding site towards starch-adsorptivity level in $\alpha$ amylase: a review on structural point of view. Enzyme Res 2017:4086845. https://doi.org/10.1155/2017/4086845

Barzkar N, Homaei A, Hemmati R, Patel S (2018) Thermostable marine microbial proteases for industrial applications: scopes and risks. Extremophiles 22:335-346. http://doi.org/10.1007/s00792-018-1009-8

Basen M, Müller V (2017) "Hot" acetogenesis. Extremophiles 21:15-26. https://doi.org/10.1007/s00792-016-0873-3

Basit A, Liu J, Miao T, Zheng F, Rahim K, Lou H and Jiang W (2018a) Characterization of two endo- $\beta-1,4$-xylanases from Myceliophthora thermophila and their saccharification efficiencies, synergistic with commercial cellulase. Front Microbiol 9:233. http://doi.org/ 10.3389/fmicb.2018.00233

Basit A, Liu J, Rahim K, Jiang W, Lou H (2018b) Thermophilic xylanases: from bench to bottle. Crit Rev Biotechnol 17:1-14. http://doi.org/10.1080/07388551.2018.1425662

Bhagia S, Akinosho H, Ferreira JF, Ferreira, Ragauskas AJ (2017) Biofuel production from Jerusalem artichoke tuber inulins: a review. Biofuel Res J 4:587-599. http://doi.org/10.18331/BRJ2017.4.2.4

Boldrin A, Balzan A, Astrup TF (2013) Energy and environmental analysis of a rapeseed biorefinery conversion process. Biomass Convers Biorefin 3:127-141. http://doi.org/10.1007/s13399-013-0071-9

Botha J, Mizrachi E, Myburg AA, Cowan DA (2018) Carbohydrate active enzyme domains from extreme thermophiles: components of a modular toolbox for lignocellulose degradation. Extremophiles 22:1-12. https://doi.org/10.1007/s00792-017-0974-7

Bou-Nader C, Montémont H, Guérineau V, Jean-Jean O, Brégeon D, Hamdane D (2018) Unveiling structural and functional divergences of bacterial tRNA dihydrouridine synthases: perspectives on the evolution scenario. Nucleic Acids Res 46:1386-1394. http://doi.org/10.1093/nar/gkx1294

Broeker J, Mechelke M, Baudrexl M, Mennerich D, Hornburg D, Mann M, Schwarz WH, Liebl W, Zverlov VV (2018) The hemicellulose-degrading enzyme system of the thermophilic bacterium Clostridium stercorarium: comparative characterisation and addition of new hemicellulolytic glycoside hydrolases. Biotechnol Biofuels 11:229. http://doi.org/10.1186/s13068-018-1228-3

Bryanskaya A, Rozanov A, Slynko N, Shekhovtsov S, Peltek S (2015) Geobacillus icigianus sp. nov., a thermophilic bacterium isolated from a hot spring. Int J Syst Evol Microbiol 65:864-869. http://doi.org/10.1099/ijs.0.000029

Cao J, Birien T, Gayet N, Huang Z, Shao Z, Jebbar M, Alain K (2017) Desulfurobacterium indicum sp. nov., a thermophilic sulfur-reducing bacterium from the Indian Ocean. Int $\mathbf{J}$ Syst Evol Microbiol 67:1665-1668. http://doi.org/10.1099/ijsem.0.001837

Chandel AK, Antunes FAF, Terán-Hilares R, Cota J, Ellilä S, Silveira MHL, dos Santos JC, da Silva SS (2018) Chapter 5-Bioconversion of hemicellulose into ethanol and valueadded products: commercialization, trends, and future opportunities, In: Chandel and Silveira (ed) Advances in sugarcane biorefinery: technologies, commercialization, 
policy issues and paradigm shift for bioethanol and by-products. Elsevier Inc. pp97134. https://doi.org/10.1016/B978-0-12-804534-3.00005-7

Chen Z, Chen H, Ni Z, Tian R, Zhang T, Jia J, Yang S (2015) Expression and characterization of a novel nitrilase from hyperthermophilic bacterium Thermotoga maritima MSB8. J Microbiol Biotechnol 25:1660-1669. http://doi.org/10.4014/jmb.1502.02032

Darby JF, Atobe M, Firth JD, Bond P, Davies GJ, O'Brien P, Hubbard RE (2017) Increase of enzyme activity through specific covalent modification with fragments. Chem Sci 8:7772-7779. http://doi.org/10.1039/c7sc01966a

David A, Govil T, Tripathi AK, McGeary J, Farrar K, Sani RJ (2018) Thermophilic anaerobic digestion: enhanced and sustainable methane production from co-digestion of food and lignocellulosic wastes. Energies 11:2058. http://doi.org/10.3390/en11082058

Diwan B, Parkhey P, Gupta P (2018) From agro-industrial wastes to single cell oils: a step towards prospective biorefinery. Folia Microbiol 63:547-568. https://doi.org/10.1007/s12223-018-0602-7

Do, Mun SH, Kim YL, Rho SJ, Park KH, Kim YR (2016) Novel formulation of low-fat spread using rice starch modified by a glucanotransferase. Food Chem 208:132-141. https://doi.org/10.1016/j.foodchem.2016.03.101

Dodsworth J, Ong J, Williams A, Dohnalkova A, Hedlund B (2015) Thermocrinis jamiesonii sp. nov., a thiosulfate-oxidizing, autotropic thermophile isolated from a geothermal spring. Int J Syst Evol Microbiol 65:4769-4775. http://doi.org/10.1099/ijsem.0.000647

Dong Y, Sanford R, Boyanov M, Kemner K, Flynn T, O’Loughlin E, Locke R, Weber J, Egan S, Fouke B (2016) Tepidibacillus decaturensis sp. nov., a microaerophilic, moderately thermophilic iron-reducing bacterium isolated from $1.7 \mathrm{~km}$ depth groundwate. Int $\mathbf{J}$ Syst Evol Microbiol 66:3964-3971. http://doi.org/10.1099/ijsem.0.001295

Dreger EB, Hakvåg S, Irla M, Brautaset T (2018) Genetic tools and techniques for recombinant expression in thermophilic Bacillaceae. Microorganisms 6:42. http://doi.org/10.3390/microorganisms6020042

Duan Y, Ming H, Dong L, Yin Y, Meng X, Zhou E, Zhang J, Nie G, Li W (2015) Cecembia rubra sp. nov., a thermophilic bacterium isolated from a hot spring sediment. Int J Syst Evol Microbiol 65:2118-2123. http://doi.org/10.1099/ijs.0.000227

Enyeart PJ, Mohr G, Ellington AD, Lambowitz AM (2014) Biotechnological applications of mobile group II introns and their reverse transcriptases: gene targeting, RNA-seq, and non-coding RNA analysis. Mob DNA 5:2. http://doi.org/10.1186/1759-8753-5-2

Ergun BG, Calik P (2016) Lignocellulose degrading extremozymes produced by Pichia pastoris: current status and future prospects. Bioprocess Biosyst Eng 39:1-36. http://doi.org/10.1007/s00449-015-1476-6

Escuder-Rodríguez JJ, DeCastro ME, Cerdán ME, Rodríguez-Belmonte E, Becerra M, González-Siso MI (2018) Cellulases from thermophiles found by metagenomics. Microorganisms 6:66. https://doi.org/10.3390/microorganisms6030066

Falcicchio P, Loo SWV, Franssen MCR, van der Oost J (2014) DHAP-dependent aldolases from hyper thermophiles: biochemistry and applications. Extremophiles 18:1-13. http://doi.org/10.1007/s00792-013-0593-X

Fernandez-Cabezon L, Galán B, García JL (2018) New insights on steroid biotechnology. Front Microbiol. 9:958. http://doi.org/10.3389/fmicb.2018.00958

Ferraz Júnior ADN, Koyama MH, MM de Araújo Júnior, Zaiat M (2016) Thermophilic anaerobic digestion of raw sugarcane vinasse. Renew Energy 89:245e252. http://dx.doi.org/10.1016/j.renene.2015.11.064

Finore I, Gioiello A, Leone L, Orlando P, Romano I, Nicolaus B, Poli A (2017) Aeribacillus composti sp. nov., a thermophilic bacillus isolated from olive mill pomace compost. Int J Syst Evol Microbiol 67:4830-4835. http://doi.org/10.1099/ijsem.0.002391 
Frazzetto G (2003) White biotechnology. EMBO Rep 4:835-837. http://doi.org/10.1038/sj.embor.embor928

Frenzel E, Legebeke J, van Stralen A, van Kranenburg R, Kuipers PO (2018) In vivo selection of sfGFP variants with improved and reliable functionality in industrially important thermophilic bacteria. Biotechnol Biofuels 11:8. https://doi.org/10.1186/s13068-017-1008-5

Gaisin V, Kalashnikov A, Grouzdev D, Sukhacheva M, Kuznetsov B, Gorlenko V (2017) Chloroflexus islandicus sp. nov., a thermophilic filamentous anoxygenic phototrophic bacterium from a geyser. Int $J$ Syst Evol Microbiol 67:1381-1386. http://doi.org/10.1099/ijsem.0.001820

Gam Z, Daumas S, Casalot L, Bartoli-Joseph M, Necib S, Linard Y, Labat M (2016) Thermanaeromonas burensis sp. nov., a thermophilic anaerobe isolated from a subterranean clay environment. Int J Syst Evol Microbiol 66:445-449. http://doi.org/10.1099/ijsem.0.000739

Ge F, Zhu L, Aang A, Song P, Li W, Tao Y, Du G (2018) Recent advances in enhanced enzyme activity, thermostability and secretion by $\mathrm{N}$-glycosylation regulation in yeast. Biotechnol Lett 40: 847-854. http://doi.org/10.1007/s10529-018-2526-3

Gidijala L, Uthoff S, van Kampen SJ, Steinbüchel A, Verhaert RMD (2018) Presence of protein production enhancers results in significantly higher methanol-induced protein production in Pichia pastoris. Microb Cell Fact 17:112. http://doi.org/10.1186/s12934018-0961-4

Glaser R, Venus J (2018) Co-fermentation of the main sugar types from a beech wood organosolv hydrolysate by several strains of Bacillus coagulans results in effective lactic acid production. Biotechnol Rep (Amst) 18:e0245. http://doi.org/10.1016/j.btre.2018.e00245

Gomri MA, Rico-Díaz A, Escuder-Rodríguez JJ, El Moulouk Khaldi T, González-Siso MI, Kharroub K (2018) Production and characterization of an extracellular acid protease from Thermophilic Brevibacillus sp. OA30 isolated from an Algerian hot spring. Microorganisms 6:31. https://doi.org/10.3390/microorganisms6020031

Gopinath SCB, Anbu P, Lakshmipriya T, Tang TH, Chen Y, Hashim U, Ruslinda AR, Md. Arshad MK (2015) Biotechnological aspects and perspective of microbial keratinase production. BioMed Res Int 140726:10. http://doi.org/10.1155/2015/140726

Grace KJ, Yuiry H, Kim L (2017) Production technology of lactase and its application in food industry application. J Sci Food Agric 1:4-6.

Grosche A, Sekaran H, Pérez-Rodríguez I, Starovoytov V, Vetriani C (2015) Cetia pacifica gen. nov., sp. nov., a chemolithoautotrophic, thermophilic, nitrate-ammonifying bacterium from a deep-sea hydrothermal vent. Int J Syst Evol Microbiol 65:1144-1150. http://doi.org/10.1099/ijs.0.000070

Guinane CM, Kent RM, Norberg S, O'Connor PM, Cotter PD, Hill C, Fitzgerald GF, Stanton C, Ross RP (2015) Generation of the antimicrobial peptide caseicin A from casein by hydrolysis with thermolysin enzymes. Int Dairy J 49:1-7. http://doi.org/10.1016/j.idairyj.2015.04.001

Guo H, Hong C, Zheng B, Lu F, Jiang D, Qin W (2017) Bioflocculants' production in a biomass-degrading bacterium using untreated corn stover as carbon source and use of bioflocculants for microalgae harvest. Biotechnol Biofuels 10:306. https://doi.org/10.1186/s13068-017-0987-6

Habib N, Khan I, Hussain F, Zhou E, Xiao M, Ahmed I, Zhi X, Li W (2017a) Caldovatus sediminis gen. nov., sp. nov., a moderately thermophilic bacterium isolated from a hot spring. Int J Syst Evol Microbiol 67:4716-4721. http://doi.org/10.1099/ijsem.0.002363 
Habib N, Khan I, Hussain F, Zhou E, Xiao M, Dong L, Zhi X, Li W (2017b) Meiothermus luteus sp. nov., a slightly thermophilic bacterium isolated from a hot spring. Int J Syst Evol Microbiol 67:2910-2914. http://doi.org/10.1099/ijsem.0.002040

Hakim A, Bhuiyan FR, Iqbal A, Emon TH, Ahmed J, Azad AK (2018) Production and partial characterization of dehairing alkaline protease from Bacillus subtilis AKAL7 and Exiguobacterium indicum AKAL11 by using organic municipal solid wastes. Heliyon 4:e00646. http://doi.org/10.1016/j.heliyon.2018.e00646

Hartley CJ, French NG, Scoble JA, Williams CC, Churches QI, Frazer AR, Taylor TC, Coia G, Simpson G, Turner NJ, Scott C (2017) Sugar analog synthesis by in vitro biocatalytic cascade: a comparison of alternative enzyme complements for dihydroxyacetone phosphate production as a precursor to rare chiral sugar synthesis. PLoS One 12:e0184183. http://doi.org/10.1371/journal.pone.0184183

Huang Y, Xiao L, Li F, Xiao X, Lin D, Long X, Wu Z (2018) Microbial degradation of pesticide residues and an emphasis on the degradation of cypermethrin and 3-phenoxy benzoic acid: a review. Molecules 23:13 http://doi.org/10.3390/molecules23092313

Huang Y, Yi Z, Jin Y, Zhao Y, He K, Liu D, Zhao D, He H, Luo H, Zhang W, Fang Y, Zhao H (2017) New microbial resource: microbial diversity, function and dynamics in Chinese liquor starter. Sci Rep 7:14577. http://doi.org/10.1038/s41598-017-14968-8

Jia X, Peng X, Liu Y, Han Y (2017) Conversion of cellulose and hemicellulose of biomass simultaneously to acetoin by thermophilic simultaneous saccharification and fermentation. Biotechnol Biofuels 10:232. https://doi.org/10.1186/s13068-017-0924-8

Joseph RC, Kim NM and Sandoval NR (2018) Recent developments of the synthetic biology toolkit for Clostridium. Front Microbiol 9:154. http://doi.org/10.3389/fmicb.2018.00154

Kadowaki MAS, Várnai A, Jameson JK, T Leite AE, Costa-Filho AJ, Kumagai PS, Prade RA, Polikarpov I, Eijsink VGH (2018) Functional characterization of a lytic polysaccharide monooxygenase from the thermophilic fungus Myceliophthora thermophila. PLoS One 13:e0202148. https://doi.org/10.1371/journal.pone.0202148

Kanoksilapatham W and Intagun W (2017) A Review: biodegradation and applications of keratin degrading microorganisms and keratinolytic enzymes, focusing on thermophiles and thermostable serine proteases. American J Appl Sci 14:1016-1023. http://doi.org/10.3844/ajassp.2017.1016.1023

Kanoksilapatham W, Pasomsup P, Keawram P, Cuecas A, Portillo MC, Gonzalez JM (2016) Fervidobacterium thailandense sp. nov., an extremely thermophilic bacterium isolated from a hot spring. Int J Syst Evol Microbiol 66:5023-5035. https://dx.doi.org/10.1099/ijsem.0.001463

Khan I, Habib N, Hussain F, Xian W, Amin A, Zhou E, Ahmed I, Zhi X, Li W (2017a) Thermus caldifontis sp. nov., a thermophilic bacterium isolated from a hot spring. Int $\mathbf{J}$ Syst Evol Microbiol 67:2868-2872. http://doi.org/10.1099/ijsem.0.002037

Khan I, Hussain F, Tian Y, Habib N, Xian W, Jiang Z, Amin A, Yuan C, Zhou E, Zhi X, Li W (2017b) Tibeticola sediminis gen. nov., sp. nov., a thermophilic bacterium isolated from a hot spring. Int J Syst Evol Microbiol 67:1133-1139. http://doi.org/10.1099/ijsem.0.001777

Khatun MM, Liu CG, Zhao XQ, Yuan WJ, Bai FW (2017) Consolidated ethanol production from Jerusalem artichoke tubers at elevated temperature by Saccharomyces cerevisiae engineered with inulinase expression through cell surface display. J Ind Microbiol Biotechnol 44:295-301. http://doi.org/10.1007/s10295-016-1881-0

Khursigara CM, Koval SF, Moyles DM, Harris RJ (2018) Inroads through the bacterial cell envelope: seeing is believing. Can J Microbiol 64:601-617. https://doi.org/10.1139/cjm2018-0091 
Kim J, Deng L, Hong E, Ryu Y (2015) Cloning and characterization of a novel thermoestable esterase from Bacillus gelatini KACC 12197. Protein Expr Purif 116: 90-97. http://doi.org/10.1016/j.pep.2015.08.009

Koeck D, Hahnke S, Zverlov V (2016a) Herbinix luporum sp. nov., a thermophilic cellulosedegrading bacterium isolated from a thermophilic biogas reactor. Int $\mathbf{J}$ Syst Evol Microbiol 66:4132-4137. http://doi.org/10.1099/ijsem.0.001324

Koeck D, Ludwig W, Wanner G, Zverlov V, Liebl W, Schwarz W (2015) Herbinix hemicellulosilytica gen. nov., sp. nov., a thermophilic cellulose-degrading bacterium isolated from a thermophilic biogas reactor. Int J Syst Evol Microbiol 65:2365-2371. http://doi.org/10.1099/ijs.0.000264

Koeck D, Mechelke M, Zverlov V, Liebl W, Schwarz W (2016b) Herbivorax saccincola gen. nov., sp. nov., a cellulolytic, anaerobic, thermophilic bacterium isolated via in sacco enrichments from a lab-scale biogas reactor. Int J Syst Evol Microbiol 66:4458-4463. http://doi.org/10.1099/ijsem.0.001374

Krefft D, Papkov A, Zylicz-Stachula A, Skowron PM (2017) Thermostable proteins bioprocesses: the activity of restriction endonuclease-methyltransferase from Thermus thermophilus (RM.TthHB27I) cloned in Escherichia coli is critically affected by the codon composition of the synthetic gene. PLoS One 12:e0186633. http://doi.org/10.1371/journal.pone.0186633

Kuancha C, Sukklang S, Detvisitsakun C, Chanton S, Apiraksakorn J (2017) Fermentable sugars production from lignocellulosic materials hydrolysis by thermophilic enzymes from Bacillus subtilis J12. Energy Procedia 138:151-156. https://doi.org/10.1016/j.egypro.2017.10.084

Laba W, Żarowska B, Chorążyk D, Pudło A, Piegza M, Kancelista A, Kopeć W (2018) New keratinolytic bacteria in valorization of chicken feather waste. AMB Express 8:9. http://doi.org/10.1186/s13568-018-0538-y

Lai Q, Cao J, Dupont S, Shao Z, Jebbar M, Alain K (2016) Thermodesulfatator autotrophicus sp. nov., a thermophilic sulfate-reducing bacterium from the Indian Ocean. Int J Syst Evol Microbiol 66:3978-3982. http://doi.org/10.1099/ijsem.0.001297

Lee LL, Blumer-Schuette SE, Izquierdo JA, Zurawski JV, Loder AJ, Conway JM, Elkins JG, Podar M, Clum A, Jones PC, Piatek MJ, Weighill DA, Jacobson DA, Adams MWW, Kelly KM (2018) Genus-wide assessment of lignocellulose utilization in the extremely thermophilic Caldicellulosiruptor by genomic, pan-genomic and metagenomic analysis. Appl Environ Microbiol 84:e02694-17. http://doi.org/10.1128/AEM.02694-17

Liang X, Whitham JM, Holwerda EK, Shao X, Tian L, Wu YW, Lombard V, Henrissat B, Klingeman DM, Yang ZK, Podar M, Richard TL, Elkins JG, Brown SD, Lynd LR (2018) Development and characterization of stable anaerobic thermophilic methanogenic microbiomes fermenting switchgrass at decreasing residence times. Biotechnol Biofuels 11:243. http://doi.org/10.1186/s13068-018-1238-1

Lincoln L and More SS (2017) Bacterial invertases: occurrence, production, biochemical characterization, and significance of transfructosylation. J Basic Microbiol 57:803-813. https://doi.org/10.1002/jobm.201700269

Liu T, Wang Y, Luo X, Li J, Reed SA, Xiao H, Young TS, Schultz, P. G. (2016) Enhancing protein stability with extended disulfide bonds. Proc Natl Acad Sci USA 113:59105915. http://doi.org/10.1073/pnas.1605363113

Ma L, Zhou L, Ruan MY, Gu JD, Mu BZ (2019) Simultaneous methanogenesis and acetogenesis from the greenhouse carbon dioxide by an enrichment culture supplemented with zero-valent iron. Renew Energy 132:861-870. https://doi.org/10.1016/j.renene.2018.08.059 
Ma S, Huang Y, Wang C, Fan H, Dai L, Zhou Z, Liu X, Deng Y (2017) Defluviitalea raffinosedens sp. nov., a thermophilic, anaerobic, saccharolytic bacterium isolated from an anaerobic batch digester treating animal manure and rice straw. Int J Syst Evol Microbiol 67:1607-1612. http://doi.org/10.1099/ijsem.0.001664

Mäkelä MR, Dilokpimol A, Koskela SM, Kuuskeri J, de Vries RP, Hildén K (2018) Characterization of a feruloyl esterase from Aspergillus terreus facilitates the division of fungal enzymes from carbohydrate esterase family of the carbohydrate-active enzymes (CAZy) database. Microb Biotechnol 11:869-880. http://doi.org/10.1111/1751-7915.13273

Malla MA, Dubey A, Yadav S, Kumar A, Hashem A and Abd_Allah EF (2018) Understanding and designing the strategies for the microbe-mediated remediation of environmental contaminants using omics approaches. Front Microbiol 9:1132. http://doi.org/10.3389/fmicb.2018.01132

Mandelli F, Couger MB, Paixão DDA, Machado CB, Carnielli CM, Aricetti JA, Polikarpov I, Prade R, Caldana C, Paes Leme AF, Mercadante AZ, Riaño-Pachón DM, Squina FM (2017) Thermal adaptation strategies of the extremophile bacterium Thermus filiformis based on multi-omics analysis. Extremophiles 21:775-788. http://doi.org/10.1007/s00792-017-0942-2

Marozava S, Mouttaki H, Müller H, Laban NA, Probst Aj, Meckenstock RU (2018) Anaerobic degradation of 1-methylnaphthalene by a member of the Thermoanaerobacteraceae contained in an iron-reducing enrichment culture. Biodegradation 29:23-39. https://doi.org/10.1007/s10532-017-9811-z

Middelveen MJ, Fesler MC, Stricker RB (2018) History of Morgellons disease: from delusion to definition. Clin Cosmet Investig Dermatol 11:71-90. http://doi.org/10.2147/CCID.S152343

Ming H, Duan Y, Yin Y, Meng X, Li S, Zhou E, Huang J, Nie G, Li W (2016) Crenalkalicoccus roseus gen. nov., sp. nov., a thermophilic bacterium isolated from alkaline hot springs. Int $J$ Syst Evol Microbiol 66:2319-2326. http://doi.org/10.1099/ijsem.0.001029

Ming H, Ji W, Li S, Zhao Z, Zhang L, Meng X, Zhou E, Nie G, Li W (2017) Laceyella thermophila sp. nov., a thermophilic bacterium isolated from a hot spring. Int J Syst Evol Microbiol 67:2953-2958. http://doi.org/10.1099/ijsem.0.002057

Mohammad BT, Al Daghistani HI, Jaouani A, Abdel-Latif S, Kennes C (2017) Isolation and characterization of thermophilic bacteria from Jordanian hot springs: Bacillus licheniformis and Thermomonas hydrothermalis isolates as potential producers of thermostable enzymes. Int J Microbiol 2017:6943952. http://doi.org/10.1155/2017/6943952

Mohr G, Ghanem E, Lambowitz AM (2010) Mechanisms used for genomic proliferation by thermophilic group II introns. PLoS Biol 8:e1000391. https://doi.org/10.1371/journal.pbio.1000391

Mohr S, Ghanem E, Smith W, Sheeter D, Qin Y, King O, Polioudakis D, Iyer VR, HunickeSmith S, Swamy S, Kuersten S, Lambowitz AM (2013) Thermostable group II intron reverse transcriptase fusion proteins and their use in cDNA synthesis and nextgeneration RNA sequencing. RNA 19:958-970. http://doi.org/10.1261/rna.039743.113

Muñoz C, Fernando FG, Rivas M, Gonzalez JM (2016) Hydrolytic enzyme activity enhanced by Barium supplementation. AIMS Microbiol 2:402-411. http://dx.doi.org/10.3934/microbiol.2016.4.402

Najar I, Sherpa M, Das S, Verma K, Dubey V, Thakur N (2018) Geobacillus yumthangensis sp. nov., a thermophilic bacterium isolated from a north-east Indian hot spring. Int $\mathrm{J}$ Syst Evol Microbiol. http://doi.org/10.1099/ijsem.0.003002 
Navone L, Speight R (2018) Understanding the dynamics of keratin weakening and hydrolysis by proteases. PLoS One 13:e0202608. https://doi.org/10.1371/journal.pone.0202608

Nishida A, Miyamoto H, Horiuchi S, Watanabe R, Morita H, Fukuda S, Ohno H, Ichinose S, Miyamoto H, Kodama H (2015) Bacillus hisashii sp. nov., isolated from the caeca of gnotobiotic mice fed with thermophile-fermented compost. Int J Syst Evol Microbiol 65:3944-3949. http://doi.org/10.1099/ijsem.0.000516

Norman J, King G, Friesen M (2017) Rubrobacter spartanus sp. nov., a moderately thermophilic oligotrophic bacterium isolated from volcanic soil. Int $\mathbf{J}$ Syst Evol Microbiol 67:3597-3602. http://doi.org/10.1099/ijsem.0.002175

Nouioui I, Carro L, García-López M, Meier-Kolthoff JP, Woyke T, Kyrpides NC, Pukall R, Klenk H-P, Goodfellow M and Göker M (2018) Genome-Based taxonomic classification of the phylum Actinobacteria. Front Microbiol 9:2007. http://doi.org/10.3389/fmicb.2018.02007

Park J, Kim M, Yun B, Han J, Kim S (2017) Pseudogracilibacillus endophyticus sp. nov., a moderately thermophilic and halophilic species isolated from plant root. Int J Syst Evol Microbiol 68:165-169. http://doi.org/10.1099/ijsem.0.002475

Park SH, Na Y, Kim J, Kang SD, Park KH (2018) Properties and applications of starch modifying enzymes for use in the baking industry. Food Sci Biotechnol 27:299-312. http://doi.org/10.1007/s10068-017-0261-5

Pechar R, Killer J, Salmonová H, Geigerová M, Švejstil R, Švec P, Sedláček I, Rada V, Benada O (2017a) Bifidobacterium apri sp. nov., a thermophilic actinobacterium isolated from the digestive tract of wild pigs (Sus scrofa). Int J Syst Evol Microbiol 67:2349-2356. http://doi.org/10.1099/ijsem.0.001956

Pechar R, Killer J, Švejstil R, Salmonová H, Geigerová M, Bunešová V, Rada V, Benada O (2017b) Galliscardovia ingluviei gen. nov., sp. nov., a thermophilic bacterium of the family Bifidobacteriaceae isolated from the crop of a laying hen (Gallus gallus $\mathrm{f}$. domestica). Int J Syst Evol Microbiol 67:2403-2411. http://doi.org/10.1099/ijsem.0.001972

Pérez-Rodríguez I, Rawls M, Coykendall D, Foustoukos D (2016) Deferrisoma palaeochoriense sp. nov., a thermophilic, iron(III)-reducing bacterium from a shallowwater hydrothermal vent in the Mediterranean Sea. Int J Syst Evol Microbiol 66:830836. http://doi.org/10.1099/ijsem.0.000798

Pezeshgi Modarres H, Mofrad MR, Sanati-Nezhad A (2018) ProtDataTherm: A database for thermostability analysis and engineering of proteins. PLoS One 13:e0191222. https://doi.org/10.1371/journal.pone.0191222

Podosokorskaya O, Merkel A, Gavrilov S, Fedoseev I, Heerden E, Cason E, Novikov A, Kolganova T, Korzhenkov A, Bonch-Osmolovskaya E, Kublanov I (2016) Tepidibacillus infernus sp. nov., a moderately thermophilic, selenate- and arsenaterespiring hydrolytic bacterium isolated from a gold mine, and emended description of the genus Tepidibacillus. Int $J$ Syst Evol Microbiol 66:3189-3194. http://doi.org/10.1099/ijsem.0.001166

Pohlschroder M, Pfeiffer F, Schulze S, Halim MFA (2018) Archaeal cell surface biogenesis. FEMS Microbiol Rev 41:694-717. https://doi.org/10.1093/femsre/fuy027

Puckett S, Trujillo C, Eoh H, Spencer MJ, Jackson M, Schnappinger D, Rhee K, Ehrt S (2014) Inactivation of fructose-1,6-bisphosphate aldolase prevents optimal cocatabolism of glycolytic and gluconeogenic carbon substrates in Mycobacterium tuberculosis. PLoS Pathog 10:e1004144. http://doi.org/10.1371/journal.ppat.1004144 
Puentes-Téllez PE, Salles JF (2018) Construction of effective minimal active microbial consortia for lignocellulose degradation. Microb Ecol 76:419-429. http://doi.org/10.1007/s00248-017-1141-5

Qiu Y, Lei P, Zhang Y, Sha Y, Zhan Y, Xu Z, Xu H, Ouyang P (2018) Recent advances in biobased multi-products of agricultural Jerusalem artichoke resources. Biotechnol Biofuels 11:151. http://doi.org/10.1186/s13068-018-1152-6

Qiu Y, Sha Y, Zhang Y, Xu Z, Li S, Lei P. Xu Z, Feng X, Xu H (2017) Development of Jerusalem artichoke resource for efficient one-step fermentation of poly- $(\gamma$-glutamic acid) using a novel strain Bacillus amyloliquefaciens NX-2S. Bioresour Technol 239:197-203. http://doi.org/10.1016/j.biortech.2017.05.005

Quehenberger J, Shen L, Albers SV, Siebers B, Spadiut O (2017) Sulfolobus- A potential key organism in future biotechnology. Front Microbiol 8:2474. http://doi.org/10.3389/fmicb.2017.02474

Ramkumar A, Sivakumar N, Gujarathi AM, Victor R (2018) Production of thermotolerant, detergent stable alkaline protease using the gut waste of Sardinella longiceps as a substrate: Optimization and characterization. Sci Rep 8:12442. https://doi.org/10.1038/s41598-018-30155-9

Reddy KV, Vijayalashmi T, Ranjit P, Raju MN (2017) Characterization of some efficient cellulase producing bacteria isolated from pulp and paper mill effluent contaminated soil. Braz Arch Biol Technol 60:e17160226. https://dx.doi.org/10.1590/1678-43242017160226

Reiner J, Jung T, Lapp C, Siedler M, Bunk B, Overmann J, Gescher J (2018) Kyrpidia spormannii sp. nov., a thermophilic, hydrogen-oxidizing, facultative autotroph, isolated from hydrothermal systems at São Miguel Island, and emended description of the genus Kyrpidia. Int J Syst Evol Microbiol. http://doi.org/10.1099/ijsem.0.003037

Rekadwad BN (2018a) Transcriptome: A tool for biotechnological applications of quorum sensing using single cell and viruses, In: Kalia (ed) Quorum Sensing and its Biotechnological Applications. Springer Nature Singapore Pte Ltd. pp143-152. https://doi.org/10.1007/978-981-13-0848-2_9

Rekadwad BN (2018b) Applications of serine/threonine protein kinases (STPK): A bus for dormancy exit, In: Kalia (ed) Quorum Sensing and its Biotechnological Applications. Springer Nature Singapore Pte Ltd. pp271-278. https://doi.org/10.1007/978-981-130848-2_18

Rekadwad BN (2018c) lux gene: quorum sensing, engineering and applications, In: Kalia VC (eds) Quorum Sensing and its Biotechnological Applications. Springer Nature Singapore Pte Ltd. pp99-106. https://doi.org/10.1007/978-981-13-0848-2_7

Rekadwad BN, Ghosh Pallab K (2018) Pseudomonas: a quorum sensing system for improved crop production. In: Quorum Sensing and its Biotechnological Applications, Editor: V. C. Kalia. Springer Nature Singapore Pte Ltd. pp181-191. https://doi.org/10.1007/978981-13-0848-2_12

Rekadwad BN, Gonzalez JM (2017) New Generation DNA Sequencing (NGS): Mining for genes and the potential of extremophiles, In: Kalia and Kumar (ed) Microbial Applications Vol.1 - Bioremediation and Bioenergy, Springer International Publishing Switzerland, AG, Springer Nature, pp.255-268. http://doi.org/10.1007/978-3-31952666-9_12

Rekadwad BN, Gonzalez JM, Khobragade CN (2017) Functional diversity and applications of mobile group II introns, In: Arora, Sajid, Kalia (ed), Drug Resistance in Bacteria, Fungi, Malaria, and Cancer, Springer International Publishing Switzerland, AG, Springer Nature. pp161-169. http://doi.org/ 10.1007/978-319-48683-3_6 
Rekadwad BN, Pathak AP (2016) First report on revelatory prokaryotic diversity of Unkeshwar hot spring (India) having biotechnological potential. Indian J Biotechnol 15:195-200. http://nopr.niscair.res.in/handle/123456789/35556

Rigoldi F, Donini S, Redaelli A, Parisini E, Gautieri A (2018) Review: engineering of thermostable enzymes for industrial applications featured. APL Bioeng 2:011501. https://doi.org/10.1063/1.4997367

Rockova S, Rada V, Nevoral J, Marsik P, Vlkova E, Bunesova V (2012) Inter-species differences in the growth of bifidobacteria cultured on human milk oligosaccharides. Folia Microbiol 57:321-324. http://doi.org/10.1007/s12223-012-0134-5

Rodrigues-Oliveira T, Belmok A, Vasconcellos D, Schuster B, Kyaw CM (2017) Archaeal Slayers: overview and current state of the art. Front Microbiol 8:2597. http://doi.org/10.3389/fmicb.2017.02597

Romero E, Grajales D, Armendáriz-Ruiz M, Ramírez-Velasco L, Rodríguez-González JA, Cira-Chávez LA, Estrada-Alvarado MI, Mateos-Díaz JC (2018) Type C feruloyl esterase from Aspergillus ochraceus: A butanol specific biocatalyst for the synthesis of hydroxycinnamates in a ternary solvent system. Electron J Biotechnol 2018:35. https://doi.org/10.1016/j.ejbt.2018.06.004

Roy K, Dey S, Uddin MK, Barua R, Hossain MT (2018) Extracellular pectinase from a novel bacterium Chryseobacterium indologenes strain SD and its application in fruit juice clarification. Enzyme Res 2018:3859752. https://doi.org/10.1155/2018/3859752

Royter M, Schmidt M, Elend C, Höbenreich H, Schäfer T, Bornscheuer UT, Antranikian G (2009) Thermostable lipases from the extreme thermophilic anaerobic bacteria Thermoanaerobacter thermohydrosulfuricus SOL1 and Caldanaerobacter subterraneus subsp. tengcongensis. Extremophiles 13:769-783. http://doi.org/10.1007/s00792-0090265-Z

Saggu SK, Mishra PC (2017) Characterization of thermostable alkaline proteases from Bacillus infantis SKS1 isolated from garden soil. PLoS One 12:e0188724. https://doi.org/10.1371/journal.pone.0188724

Sandri IG and da Silveira MM (2018) Production and application of pectinases from Aspergillus niger obtained in solid state cultivation. Beverages 4:48. http://doi.org/10.3390/beverages4030048

Saroj P, Manasa P, Narasimhulu K (2018) Characterization of thermophilic fungi producing extracellular lignocellulolytic enzymes for lignocellulosic hydrolysis under solid-state fermentation. Bioresour Bioprocess 20185:31. https://doi.org/10.1186/s40643-0180216-6

Schröder C, Janzer VA, Schirrmacher G, Claren G, Antranikian G (2017) Characterization of two novel heat-active $\alpha$-galactosidases from thermophilic bacteria. Extremophiles 21:85-94. https://doi.org/10.1007/s00792-016-0885-z

Schuerg T, Prahl JP, Gabriel G, Harth S, Tachea F, Chen CS, Miller M, Masson F, He Q, Brown S, Mirshiaghi M, Liang L, Tom LM, Tanjore D, Sun N, Pray TR, Singer SW (2017) Xylose induces cellulase production in Thermoascus aurantiacus. Biotechnol Biofuels 10:271. http://doi.org/10.1186/s13068-017-0965-z

Scully SM, Orlygsson J (2015) Recent advances in second generation ethanol production by thermophilic bacteria. Energies 8:1-30. http://doi.org/10.3390/en8010001

Sierra-Garcia IN, Dellagnezze BM, Santos VP, Chaves MR, Capilla R, Santos Neto EV, Gray N, Oliveira VM (2017) Microbial diversity in degraded and non-degraded petroleum samples and comparison across oil reservoirs at local and global scales. Extremophiles 21:211-229. https://doi.org/10.1007/s00792-016-0897-8

Singh R, Kumar M, Mittal A, Mehta PK (2016) Microbial enzymes: industrial progress in 21st century. 3 Biotech 6:174. http://doi.org/10.1007/s13205-016-0485-8 
Singh S, Gupta P, Bajaj BK (2018) Characterization of a robust serine protease from Bacillus subtilis K-1. J Basic Microbiol 58:88-98. https://doi.org/10.1002/jobm.201700357

Sitthikitpanya S, Reungsang A, Prasertsan P (2018) Two-stage thermophilic bio-hydrogen and methane production from lime-pretreated oil palm trunk by simultaneous saccharification and fermentation. Int $J$ Hydrogen Energy 43:4284-4293. https://doi.org/10.1016/j.ijhydene.2018.01.063

Slobodkin A, Slobodkina G, Panteleeva A, Chernyh N, Novikov A, Bonch-Osmolovskaya E (2016) Dissulfurimicrobium hydrothermale gen. nov., sp. nov., a thermophilic, autotrophic, sulfur-disproportionating deltaproteobacterium isolated from a hydrothermal pond. Int $J$ Syst Evol Microbiol 66:1022-1026. http://doi.org/10.1099/ijsem.0.000828

Slobodkina G, Baslerov R, Novikov A, Bonch-Osmolovskaya E, Slobodkin A (2017b) Thermodesulfitimonas autotrophica gen. nov., sp. nov., a thermophilic, obligate sulfitereducing bacterium isolated from a terrestrial hot spring. Int J Syst Evol Microbiol 67:301-305. http://doi.org/10.1099/ijsem.0.001619

Slobodkina G, Kolganova T, Kopitsyn D, Viryasov M, Bonch-Osmolovskaya E, Slobodkin A (2016a) Dissulfurirhabdus thermomarina gen. nov., sp. nov., a thermophilic, autotrophic, sulfite-reducing and disproportionating deltaproteobacterium isolated from a shallow-sea hydrothermal vent. Int $J$ Syst Evol Microbiol 66:2515-2519. http://doi.org/10.1099/ijsem.0.001083

Slobodkina G, Kovaleva O, Miroshnichenko M, Slobodkin A, Kolganova T, Novikov A, van Heerden E, Bonch-Osmolovskaya E (2015) Thermogutta terrifontis gen. nov., sp. nov. and Thermogutta hypogea sp. nov., thermophilic anaerobic representatives of the phylum Planctomycetes. Int J Syst Evol Microbiol 65:760-765. http://doi.org/10.1099/ijs.0.000009

Slobodkina G, Panteleeva A, Beskorovaynaya D, Bonch-Osmolovskaya E, Slobodkin A (2016b) Thermostilla marina gen. nov., sp. nov., a thermophilic, facultatively anaerobic planctomycete isolated from a shallow submarine hydrothermal vent. Int J Syst Evol Microbiol 66:633-638. http://doi.org/10.1099/ijsem.0.000767

Slobodkina G, Reysenbach A, Kolganova T, Novikov A, Bonch-Osmolovskaya E, Slobodkin A (2017a) Thermosulfuriphilus ammonigenes gen. nov., sp. nov., a thermophilic, chemolithoautotrophic bacterium capable of respiratory ammonification of nitrate with elemental sulfur. Int J Syst Evol Microbiol 67:3474-3479. http://doi.org/10.1099/ijsem.0.002142

Song L, Ouedraogo J-P, Kolbusz M, Nguyen TTM, Tsang A (2018) Efficient genome editing using tRNA promoter-driven CRISPR/Cas9 gRNA in Aspergillus niger. PLoS One 13:e0202868. https://doi.org/10.1371/journal.pone.0202868

Steinsbu B, Røyseth V, Thorseth I, Steen I (2016) Marinitoga arctica sp. nov., a thermophilic, anaerobic heterotroph isolated from a Mid-Ocean Ridge vent field. Int J Syst Evol Microbiol 66:5070-5076. http://doi.org/10.1099/ijsem.0.001472

Strang O, Acs N, Wirth R, Maroti G, an Bagi Z, Rakhely G, Kovacs KL (2017) Bioaugmentation of the thermophilic anaerobic biodegradation of cellulose and corn stover. Anaerobe 46:104e113. http://doi.org/10.1016/j.anaerobe.2017.05.014

Suaria G, Aliani S, Merlino S and Abbate M (2018) The occurrence of paraffin and other petroleum waxes in the marine environment: a review of the current legislative framework and shipping operational practices. Front Mar Sci 5:94. http://doi.org/10.3389/fmars.2018.00094

Sundarrajan S, Rao S, Padmanabhan S (2018) Cloning and high-level expression of Thermus thermophilus RecA in E. coli: purification and novel use in HBV diagnostics. Braz J Microbiol 49: 848-855. https://doi.org/10.1016/j.bjm.2018.03.007 
Tamazawa S, Mayumi D, Mochimaru H, Sakata S, Maeda H, Wakayama T, Ikarashi M, Kamagata Y, Tamaki H (2017) Petrothermobacter organivorans gen. nov., sp. nov., a thermophilic, strictly anaerobic bacterium of the phylum Deferribacteres isolated from a deep subsurface oil reservoir. Int J Syst Evol Microbiol 67:3982-3986. http://doi.org/10.1099/ijsem.0.002234

Tian Y, Xu W, Zhang W, Zhang T, Guang C, Mu W (2018) Amylosucrase as a transglucosylation tool: From molecular features to bioengineering applications. Biotechnol Adv 36:1540-1552. http://doi.org/10.1016/j.biotechadv.2018.06.010

Ueno T, Niimi H, Yoneda N, Yoneda S, Mori M, Tabata H, Minami H, Saito S, Kitajima I (2015) Eukaryote-made thermostable DNA polymerase enables rapid PCR-based detection of Mycoplasma, Ureaplasma and other bacteria in the amniotic fluid of preterm labor cases. PLoS One 10:e0129032. https://doi.org/10.1371/journal.pone.0129032

Uraji M, Arima J, Inoue Y, Harazono K, Hatanaka T (2014) Application of two newly identified and characterized feruloyl esterases from Streptomyces sp. in the enzymatic production of ferulic acid from agricultural biomass. PLoS One 9:e104584. https://doi.org/10.1371/journal.pone.0104584

Vanz AL, Lünsdorf H, Adnan A, Nimtz M, Gurramkonda C, Khanna N, Rinas U (2012) Physiological response of Pichia pastoris GS115 to methanol-induced high level production of the Hepatitis B surface antigen: catabolic adaptation, stress responses, and autophagic processes. Microb Cell Fact 11:103. http://doi.org/10.1186/1475-285911-103

Venev SV and Zeldovich KB (2017) Thermophilic adaptation in prokaryotes is constrained by metabolic costs of proteostasis. Mol Biol Evol 35:211-224 http://doi.org/10.1093/molbev/msx282

Verma A, Singh H, Anwar S, Chattopadhyay A, Tiwari KK, Kaur S, Dhilon GS (2017) Microbial keratinases: industrial enzymes with waste management potential. Crit Rev Biotechnol 37:476-491. http://doi.org/10.1080/07388551.2016.1185388

Verma ML and Kanwar SS (2012) Harnessing the potential of thermophiles: the variants of extremophiles. Dyn Biochem Process Biotechnol Mol Biol 6:28-39.

Visone V, Han W, Perugino G, del Monaco G, She Q, Rossi M, Valenti A, Ciaramella M (2017) In vivo and in vitro protein imaging in thermophilic archaea by exploiting a novel protein tag. PLoS One 12:e185791. https://doi.org/10.1371/journal.pone.0185791

Vitale P, Perna FM, Agrimi G, Pisano I, Mirizzi F, Capobianco RV, Capriati V (2018) Wholecell biocatalyst for chemoenzymatic total synthesis of rivastigmine. Catalysts 8:55. http://doi.org/10.3390/catal8020055

Wang B, Ji S, Tian X, Qu L, Li F (2015) Brassicibacter thermophilus sp. nov., a thermophilic bacterium isolated from coastal sediment. Int J Syst Evol Microbiol 65:2870-2874. http://doi.org/10.1099/ijs.0.000348

Wang L, Qian Y, Cao Y, Huang Y, Chang Z, Huang H (2017) Production and characterization of keratinolytic proteases by a chicken feather-degrading thermophilic strain, Thermoactinomyces sp. YT06. J Microbiol Biotechnol 27:2190-2198. https://doi.org/10.4014/jmb.1705.05082

Watanabe M, Kojima H, Fukui M (2015) Limnochorda pilosa gen. nov., sp. nov., a moderately thermophilic, facultatively anaerobic, pleomorphic bacterium and proposal of Limnochordaceae fam. nov., Limnochordales ord. nov. and Limnochordia classis nov. in the phylum Firmicutes. Int $J$ Syst Evol Microbiol 65:2378-2384. http://doi.org/10.1099/ijs.0.000267 
Watanabe M, Matsuzawa T, Yaoi K (2018) Rational protein design for thermostabilization of glycoside hydrolases based on structural analysis. Appl Microbiol Biotechnol 102:8677-8684. http://doi.org/10.1007/s00253-018-9288-7

Widowati E, UtamiR, Kalistyatika K (2017) Screening and characterization of polygalacturonase as potential enzyme for keprok garut orange (Citrus nobilis var. chrysocarpa) juice clarification. J Phys Conf Ser 909:012088. https://doi.org/10.1088/1742-6596/909/1/012088

Wolfson SJ, Porter AW, Kerkhof LJ, McGuinness LM, Prince RC, Young LY (2018) Sulfatereducing naphthalene degraders are picky eaters. Microorganisms 6:59. https://doi.org/10.3390/microorganisms6030059

Wu H, Liu B, Pan S (2015) Thermoactinomyces guangxiensis sp. nov., a thermophilic actinomycete isolated from mushroom compost. Int J Syst Evol Microbiol 65:28592864. http://doi.org/10.1099/ijs.0.000342

Wu H, Liu B, Pan S (2016) Crenalkalicoccus roseus gen. nov., sp. nov., a thermophilic bacterium isolated from alkaline hot springs. Int J Syst Evol Microbiol 66:1990-1995. http://doi.org/10.1099/ijsem.0.000976

Yang G, Chen J, Zhou S (2015) Novibacillus thermophilus gen. nov., sp. nov., a Gramstaining-negative and moderately thermophilic member of the family Thermoactinomycetaceae. Int $J$ Syst Evol Microbiol 65:2591-2597. http://doi.org/10.1099/ijs.0.000306

Yang G, Guo J, Zhuang L, Yuan Y, Zhou S (2016) Desulfotomaculum ferrireducens sp. nov., a moderately thermophilic sulfate-reducing and dissimilatory $\mathrm{Fe}$ (III)-reducing bacterium isolated from compost. Int $J$ Syst Evol Microbiol 66:3022-3028. http://doi.org/10.1099/ijsem.0.001139

Yang L, Muhadesi J, Wang M, Wang B, Liu S, Jiang C (2018a) Thauera hydrothermalis sp. nov., a thermophilic bacterium isolated from hot spring. Int J Syst Evol Microbiol 68:3163-3168. http://doi.org/10.1099/ijsem.0.002960

Yang Z, Zhang Z (2018b) Production of (2R, 3R)-2, 3-butanediol using engineered Pichia pastoris: strain construction, characterization and fermentation. Biotechnol Biofuels 11:35. https://doi.org/10.1186/s13068-018-1031-1

Yao S, Zhai L, Xin C, Liu Y, Xu L, Zhang X, Zhao T, Zhang L, Cheng C (2016) Scopulibacillus daqui sp. nov., a thermophilic bacterium isolated from high temperature daqu. Int J Syst Evol Microbiol 66:4723-4728. http://doi.org/10.1099/ijsem.0.001417

Yin X, Hu D, Li JF, He Y, Zhu TD, Wu MC. (2015a) Contribution of disulfide bridges to the thermostability of a type a feruloyl esterase from Aspergillus usamii. PLoS One 10:e0126864. http://doi.org/10.1371/journal.pone.0126864

Yin X, Li JF, Wang CJ, Hu D, Wu Q, Gu Y, Wu MC (2015b) Improvement in the thermostability of a type-A feruloyl esterase, AuFaeA, from Aspergillus usamii by iterative saturation mutagenesis. Appl Microbiol Biotechnol 99:10047-10056. http://doi.org/10.1007/s00253-015-6889-2

Yokoyama K, Lilla EA (2018) C-C bond forming radical SAM enzymes involved in the construction of carbon skeletons of cofactors and natural products. Nat Prod Rep 35:660-694. http://doi.org/10.1039/c8np00006a

Zarafeta D, Kissas D, Sayer C, Gudbergsdottir SR, Ladoukakis E, Isupov MN, Chatziioannou A, Peng X, Littlechild JA, Skretas G, Kolisis FN (2016a) Discovery and characterization of a thermostable and highly halotolerant gh5 cellulase from an Icelandic hot spring isolate. PLoS One 11:e0146454. http://doi.org/10.1371/journal.pone.0146454

Zarafeta D, Moschidi D, Ladoukakis E, Gavrilov S, Chrysina ED, Chatziioannou A, Kublanov I, Skretas G, Kolisis FN (2016b) Metagenomic mining for thermostable 
esterolytic enzymes uncovers a new family of bacterial esterases. Sci Rep 6:38886. http://doi.org/10.1038/srep38886

Zarafeta D, Szabo Z, Moschidi D, Phan H, Chrysina ED, Peng X, Ingham CJ, Kolisis FN and Skretas G (2016c) EstDZ3: A new esterolytic enzyme exhibiting remarkable thermostability. Front Microbiol 7:1779. http://doi.org/10.3389/fmicb.2016.01779

Zeng X, Zhang Z, Li X, Jebbar M, Alain K, Shao Z (2015) Caloranaerobacter ferrireducens sp. nov., an anaerobic, thermophilic, iron (III)-reducing bacterium isolated from deepsea hydrothermal sulfide deposits. Int $J$ Syst Evol Microbiol 65:1714-1718. http://doi.org/10.1099/ijs.0.000165

Zhang H, Feng J, Chen S, Li B, Sekar R, Zhao Z, Jia J, Wang Y and Kang P (2018) Disentangling the drivers of diversity and distribution of fungal community composition in wastewater treatment plants across spatial scales. Front Microbiol 9:1291. http://doi.org/10.3389/fmicb.2018.01291

Zheng T, Lanahan AA, Lynd LR, Olson DG (2018) The redox-sensing protein Rex modulates ethanol production in Thermoanaerobacterium saccharolyticum. PLoS One 13:e0195143. https://doi.org/10.1371/journal.pone.0195143

Zhou B, Hogg PJ, Gräter F (2017) One-way allosteric communication between the two disulfide bonds in tissue factor. Biophys $\mathrm{J}$ 112:78-86. http://doi.org/10.1016/j.bpj.2016.12.003

Zhou EM, Xian WD, Mefferd CC, Thomas SC, Adegboruwa AL, Williams N, Murugapiran SK, Dodsworth JA, Ganji R, Li MM, Ding YP, Liu L, Woyke T, Li WJ, Hedlund BP (2018) Thermus sediminis sp. nov., a thiosulfate-oxidizing and arsenate-reducing organism isolated from Little Hot Creek in the Long Valley Caldera, California. Extremophiles 22:983-991. http://doi.org/10.1007/s00792-018-1055-2 